BANCA D'ITALIA

E U ROS I S T E M A

Temi di discussione

(Working Papers)

Judicial efficiency and bank eredit to firms

by Giacomo Rodano 

$\mathbb{B}^{-3}$ BANCA D'ITALIA

E U ROS I S T E MA

\section{Temi di discussione}

(Working Papers)

Judicial efficiency and bank credit to firms

by Giacomo Rodano

Number 1322 - March 2021 
The papers published in the Temi di discussione series describe preliminary results and are made available to the public to encourage discussion and elicit comments.

The views expressed in the articles are those of the authors and do not involve the responsibility of the Bank.

Editorial Board: Federico Cingano, Marianna Riggi, Monica Andini, Audinga Baltrunaite, Marco Bottone, Davide Delle Monache, Sara Formai, Francesco Franceschi, Adriana Grasso, Salvatore lo Bello, Juho Taneli Makinen, Luca Metelli, Marco Savegnago.

Editorial Assistants: Alessandra Giammarco, Roberto Marano.

ISSN 1594-7939 (print)

ISSN 2281-3950 (online)

Printed by the Printing and Publishing Division of the Bank of Italy 


\title{
JUDICIAL EFFICIENCY AND BANK CREDIT TO FIRMS
}

\author{
by Giacomo Rodano*
}

\begin{abstract}
This paper empirically analyses the effect of judicial efficiency on bank credit contract terms for the universe of Italian corporations borrowing from the banking sector. Exploiting within-country variation in the length of bankruptcy proceedings across different jurisdictions, the paper uses a spatial regression discontinuity design that compares credit conditions applied to firms located in municipalities on different sides of jurisdiction borders, controlling for bank characteristics. The results show that judicial efficiency is associated with a reduction in the cost of credit as well as with an increase in its availability for firms, in particular for those at high risk of default. Judicial efficiency increases leverage and investment for high-risk firms. All these results suggest that the banking system tilts credit conditions in favour of safe firms as judicial inefficiency increases. Finally, judicial efficiency is also associated with a reduction in both the stock and the flow of non-performing loans.
\end{abstract}

JEL Classification: G21, G33, K12, K15.

Keywords: judicial efficiency, creditor rights, loan contractual terms, spatial discontinuity approach.

DOI: $10.32057 / 0 . T D .2021 .1322$

\section{Contents}

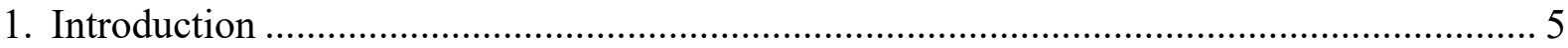

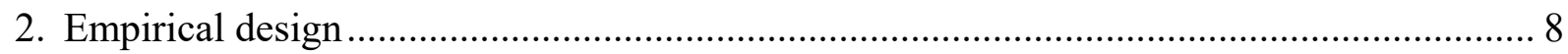

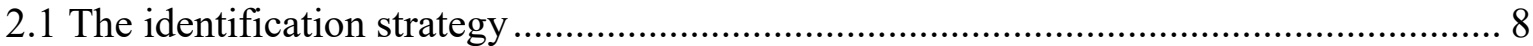

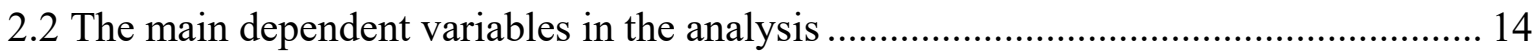

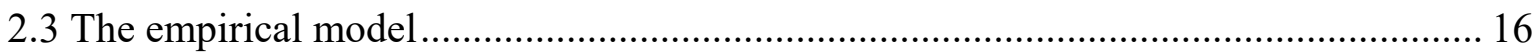

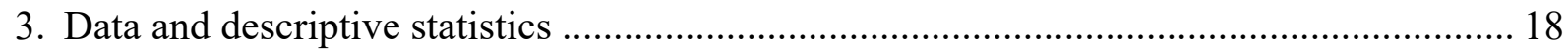

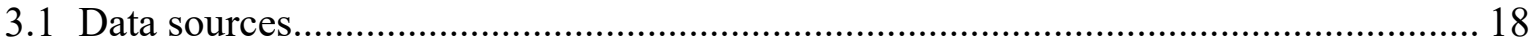

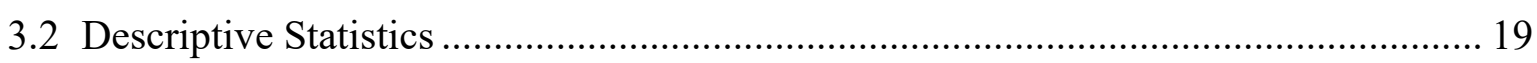

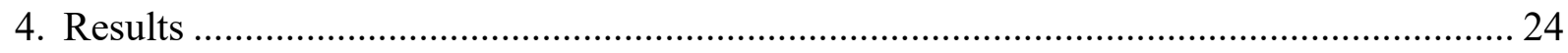

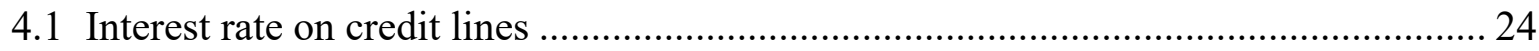

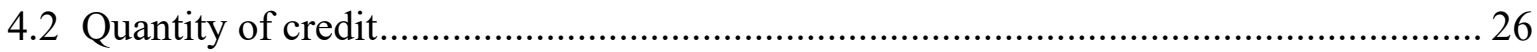

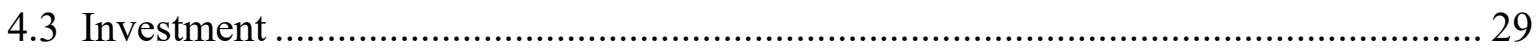

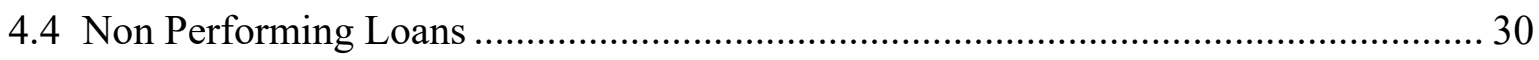

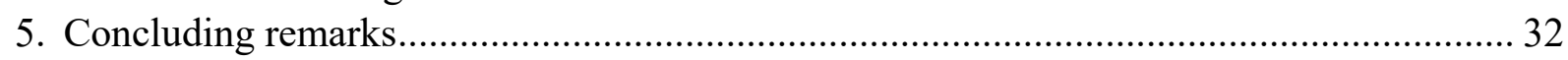

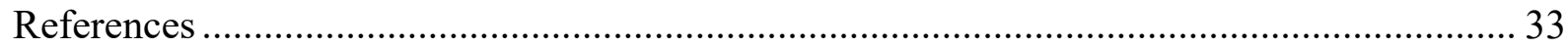

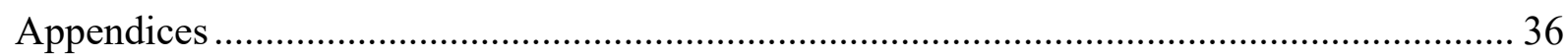

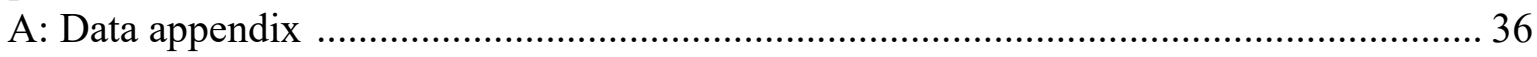

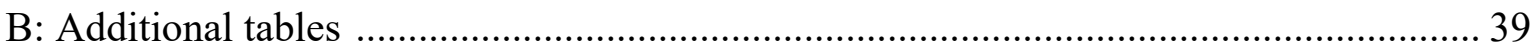

\footnotetext{
* Bank of Italy, Directorate General of Economics, Statistics, and Research, Directorate for Structural Economic Analysis.
} 



\section{$1 \quad$ Introduction $^{1}$}

A wide literature has shown that the strength of creditor legal protection affects the availability of credit and influences the terms of financial contracts. ${ }^{2}$ The degree of protection that legal institutions provide creditors depends both on the content of the law (e.g. creditor powers in bankruptcy procedures) and on its enforcement through courts (e.g. time and cost of bankruptcy procedures).

This paper focuses on court enforcement of bankruptcy law and investigates empirically the effects of the length of bankruptcy procedures on bank credit contractual terms and firms' borrowing and investment decisions of Italian firms. Using a unique dataset, at the firm-bank level, about bank funding to the universe of corporations in Italy with at least 30000 euros of bank debt, the paper adopts a spatial regression discontinuity design that compares credit conditions applied to firms located in municipalities on different sides of jurisdiction borders, controlling for bank characteristics. Therefore, the analysis can isolate the effects of judicial enforcement from other formal and informal institutions that may affect bank lending to firms. Exploiting the granularity of data, the paper can shed some light on several novel aspects of how court efficiency affects firm credit through the credit supply, in particular documenting a significant heterogeneity across firm with different default risk.

The paper shows that lengthy bankruptcy procedures are associated with higher interest rates on revolving credit lines and lower credit granted by the same bank to otherwise similar firms. Reducing the duration of bankruptcy procedures by about 70 months - from the $75^{\text {th }}$ to the $25^{\text {th }}$ percentile of the distribution of the length of bankruptcy trials at the court level - is associated with lower interest rate on credit lines by about 14 to 18 basis points for average firm, according to the different specifications, and by 22 basis points for firms with a high risk of default, against an average rate of $7.3 \%$ in our sample. The same improvement in court efficiency is associated with an increase in the granted credit on the lines of $5.7 \%$, with substantial differences according to firm's risk of default, $3.5 \%$ and $6.9 \%$ for low and high risk firms respectively. The same heterogeneity with respect to firms' risk is present also in the effects of court efficiency on the extensive margin of credit, leverage and investment at the firm level. The improvement in court efficiency is associated with a higher probability of obtaining a new term loan for high risk firms (about 1.7\% points against an average probability of $43 \%$ ), while it has no significant effect for the safe ones. Judicial efficiency is associated with higher leverage for high risk firms, but with lower leverage for the safe ones. Where courts are more efficient high risk firms invest more, but there are no effects for the safe ones. Finally, court efficiency is negatively correlated the probability of observing a firm-bank relationship with some NPLs (stock of existing NPLs), and the probability of

\footnotetext{
${ }^{1}$ This paper is a completely revised version of an old project joint with Silvia Giacomelli and Carlo Menon, which I would like to thank for discussions, ideas and for providing me with their GIS data. I would also like to thank Massimiliano Affinito, Marcello Bofondi, Federico Cingano, Guzmán González-Torres, Francesco Manaresi, Sauro Mocetti, Tommaso Orlando, Paolo Sestito, Enrico Sette, Marco Tonello and two anonymous referees for useful comments and discussions. Graziella Capello and Roberto Felici provided invaluable help in solving data related issues. The views expressed are those of the author and do not necessarily reflect those of the Bank of Italy.

${ }^{2}$ See, for example, La Porta et al. (1997), Djankov et al. (2007), Laeven and Majnoni (2005), Bae and Goyal (2009), Qian and Strahan (2007) and Lerner and Schoar (2005).
} 
a new relationship turning bad (flow of new NPLs), in particular for high risk firms.

By isolating the effects of court enforcement on credit conditions, the evidence provided in the paper reveals two interesting novel features of how bank credit and firms' decisions react to court efficiency. First, the significant heterogeneity in how court efficiency is associated with credit conditions according to firms' risk suggests that banks tilt credit conditions significantly in favor of low risk firms when court efficiency worsens, which leads to mis-allocation of credit with respect to firms' risk. Second, the relatively small magnitude of the effects of court efficiency on the interest rates, when compared with those on the granted credit, suggests that the quantitatively more relevant margin of adjustment in the supply of credit is through quantity rather than price. Finally, the results provide evidence consistent with two different channels through which efficiency in enforcement of credit contract affects bank credit to firms: the present value of the amount recovered by the banks in the event of bankruptcy.

By increasing the present value of the amount recovered by the banks in the event of bankruptcy, thereby reducing the loss given default, more efficient (faster) procedures should determine better contractual conditions for borrowers. Furthermore, if a firm has a very low probability of default, and therefore of being involved in a bankruptcy proceeding, its bank credit conditions will be relatively less affected (if at all) by the efficiency in enforcing bankruptcy law (Rodano et al., 2016). Therefore, conditional on other firm and bank characteristics, bank loans to firms operating in areas where enforcement of creditor rights is less efficient should display worse contractual conditions, in particular for firms with a higher risk of default. At the same time, if faster courts reduce the time NPLs are present on bank balance sheet, an improvement in court efficiency might be associated with an increase in credit supply and better credit conditions, in particular for high risk firms.

Debt is a security with several different characteristics like non-contingent payment stream, right for the creditor to foreclose on the debtor's assets in default or priority in bankruptcy (see Hart and Moore, 1998). There are several types of debt contracts (e.g. revolving credit lines, term loans) and each type of debt contract is in itself complex, with different characteristics like interest rate, amount, maturity, presence of collateral or covenants. Furthermore, these different features of credit contracts interact in complex ways among themselves (e.g. the interest rate is usually negatively correlated with exposure) and with firm characteristics, and this interaction might be affected by judicial efficiency.

To deal with these complex relationships, the paper focuses on few specific characteristics of bank credit to firms, in particular on the interest rate and granted credit on revolving credit lines, which are a short term, usually unsecured, standardized credit contract, whose only two terms (granted credit and interest rate) can be changed relatively quickly by the bank. To consider the extensive margin of credit, the paper also analyses the probability of a firm receiving a new term loan, a broad measure which is less affected by the inherently complex nature of debt contracts than specific aspects of term loan contracts. Using firms' balance sheet data, the paper also studies leverage and investment decisions of the firm. Finally, as a first attempt to investigate also the second potential channels through which court efficiency can affect bank credit to firms, the paper analyses the effects of court efficiency on the stock of existing non performing loans (NPLs) and on the flow of new ones. 
To identify the effect of court enforcement on credit contracts it is necessary to disentangle the effect of judicial enforcement from other formal and informal institutions that may affect bank lending to firms. Therefore, the empirical strategy adopts a spatial regression discontinuity design that exploits variation in courts efficiency across jurisdictions while holding the relevant legal framework constant. Following Giacomelli and Menon (2017), the paper considers lending relationships of the same bank with firms located in municipalities on either side of court jurisdiction borders in Italy. At jurisdiction borders judicial efficiency in bankruptcy procedures displays a discrete jump determining an exogenous variation in creditor protection for the same bank lending to firms located on either side of the border. Identification is based on the assumption that unobserved local characteristics that might affect bank lending to firms do not vary discontinuously across jurisdiction borders.

Italy offers a particularly interesting setting to study the effect of contract enforcement on bank credit. First and most important, in Italy there is a uniform bankruptcy law valid for all the regions, but there is substantial heterogeneity in court efficiency within the country, even within the same region (Giacomelli et al., 2017). Furthermore, Italian bankruptcy law establishes that bankruptcy procedures are assigned to courts on the basis of debtors' headquarter location: this creates a tight link between firms' headquarter municipality and the relevant court, as well as limiting the possibility of forum shopping. Second, banking finance is the major source of finance for limited liability companies in Italy, accounting for around $40 \%$ of funding sources in our sample. Finally, the Italian judicial system is rather inefficient by international standards: according to the World Bank's Doing Business report for 2018, Italy ranks $21^{\text {st }}$ in Resolving Insolvency and $30^{\text {th }}$ in Enforcing Contracts among 33 high income OECD countries. Furthermore, court inefficiency in credit recovery might have contributed to a substantial increase in NPLs during the global financial crisis. Accornero et al. (2017) documents that since 2008 the stock of NPLs on the balance sheets of Italian banks have tripled, reaching 18 per cent of total loans in 2015 .

Several papers analysing the effects of the legal system on the functioning of credit markets have adopted a cross-country perspective (Djankov et al., 2007; Laeven and Majnoni, 2005; Qian and Strahan, 2007; Bae and Goyal, 2009). However, this approach does not allow to isolate the effect of legal creditor protection from other institutions of a country, including the functioning of the court system. Other studies adopted a within-country perspective that, holding constant the substantive legal setting, therefore focusing on court enforcement. However Jappelli et al. (2005), by using aggregate data at the province level in Italy, and Fabbri (2010) on regions in Spain do not address the identification issues related to the possible influences of other local institutional factors on credit financing and are thus unable to isolate the role of courts. Furthermore they can not differentiate the effects of judicial efficiency according to firms' risk of default, and thus to uncover a significant heterogeneity in the effects.

More recent studies are closer to this paper as they exploit exogenous variations in the duration of judicial proceedings involving debt contracts, following substantial reform of bankruptcy procedures, to analyze their effects on the functioning of credit markets in India (Visaria, 2009; Chemin, 2012). The main differences with this paper lie in the identification strategy employed and in the focus on bankruptcy procedures in developed markets rather than developing 
ones. Moreover, given the the richness of the data, this paper can analyse the effects on the different dimension of credit contracts as well as differential responses across firms risk. Furthermore, the natural experiments exploited by these papers are usually associated with comprehensive reforms of bankruptcy system, making the task of disentangling the effects of the changes in the content of the law from those of changes in its enforcement a difficult one. Differently from these papers, the identifying variation in court efficiency in this paper does not come from a reform of the bankruptcy system but from the discrete jumps in judicial efficiency observed at jurisdiction borders.

The variation in courts enforcement has been exploited to address different research questions by Ponticelli and Alencar (2016) and Schiantarelli et al. (2020). The first paper uses the differences in the functioning of Brazilian courts to analyze the effect of a reform of the Brazilian bankruptcy law on firms productivity and credit access. The second paper shows that Italian firms delay payment to banks weakened by past loan losses in particular where legal enforcement of collateral recovery is slow. A completely different approach to the same topic of this paper is adopted by González-Torres and Rodano (2020) that builds a dynamic model of heterogeneous firms where the quality of credit contract enforcement affects firms' access to credit to analyze the extend to which court efficiency determines aggregate productivity. ${ }^{3}$

Finally, the identification strategy based on spatial discontinuity used in this paper is drawn from Giacomelli and Menon (2017), that investigates the link between judicial efficiency and firm size in Italy and finds that the duration of civil proceedings negatively affect the average size of manufacturing firms. Rodano et al. (2016) exploits the same measure of firm's default risk used in this paper to analyse the effects of two major bankruptcy reforms in Italy in 2005 and 2006, but it does not address directly the issue of court efficiency.

The remainder of this paper is organized as follows. Section 2 presents the details of the identification strategy and the empirical model adopted in the paper. Section 3 discusses the data and presents some descriptive statistics. Results are presented in Section 4 while Section 5 concludes.

\section{Empirical design}

\subsection{The identification strategy}

The identification of the effects of courts' efficiency on credit conditions is difficult because court functioning is likely to be strongly correlated with other formal institutions and with informal factors. The effect of formal institutions can be controlled for by looking at variation of courts' efficiency in a withincountry framework, when bankruptcy law is established at the national level while judicial enforcement varies at local level. However, in this framework, the main identification challenge is to disentangle the effect of judicial enforcement from other institutional factors (formal and informal) that may influence

\footnotetext{
${ }^{3}$ This paper is also related to the literature on the influences of local factors on financial behavior in Italy. Guiso et al. (2004), exploiting social capital differences within Italy, showed that social capital affects financial behavior of households and favors their access to credit. Bonaccorsi di Patti (2009) analyzed the impact of crime rates at provincial level finding that where crime rates are higher borrowers pay higher interest rates and pledge more collateral.
} 
bank-firm lending relationships and may vary significantly at local level. Disentangling the effect of judicial enforcement from these informal institutions or social norms, like for instance social capital, trust, or crime, is however a much more difficult challenge, as those variables are very hard to measure, but have been proven to have a non-negligible effects on the economy (Guiso et al., 2004; Bonaccorsi di Patti, 2009).

The empirical methodology to address this identification issue is based on a spatial regression discontinuity design (Black, 1999; Holmes, 1998). Following Giacomelli and Menon (2017) the analysis restricts the sample to firms located in proximity of a spatial discontinuity that affect only court efficiency, and mean-differentiates the control variables within the group of observations which share the same discontinuity. Therefore the lending relationships by the same bank with firms located in municipalities on either side of jurisdiction borders are considered. At jurisdiction borders judicial efficiency displays a discrete variation. As in Italy bankruptcy cases are automatically assigned to courts on the basis of debtor's location, the variation in judicial efficiency at jurisdiction borders determines an exogenous variation in credit contract for the same bank lending to firms located on either side of the border.

The validity of the identification strategy is based on two assumptions: $i$ ) the relevance assumption presumes that the spatial discontinuity introduces a discrete and significant jump in the variable of interest; ii) the exogeneity assumption requires that unobserved local characteristics that might affect bank-firm lending relationships do not vary discontinuously at jurisdiction borders. The Italian judicial system, in particular with respect to bankruptcy law, presents some features that make it an ideal environment for the application of this methodology, as it can be argued that both required assumptions are likely to hold in the Italian case.

The relevance assumption requires that jurisdiction borders do correspond to discrete jumps in the duration of bankruptcy procedures for firms located at different sides. Figure 1 shows the distribution of the average duration of bankruptcy procedures at court level: there is a fair amount of variation even within the same geographical areas, between neighboring courts. The variability in court efficiency documented in Figure 1 induces a sharp discontinuity in court efficiency at the jurisdiction border. Figure 2 reports the kernel density distributions of the average length of bankruptcy trials (in months) across different border groups, for the efficient (blue) and the inefficient (red) side within the same border group, as well as the means for both sides (vertical dashed lines). The difference in length of trials from the efficient and the inefficient side within the same border group is substantial (on average about 2.5 years) and statistically significant. ${ }^{4}$

There is no clear evidence on the determinants of the high variability in the duration of bankruptcy procedures. In the Italian judicial system there are no specialized courts for bankruptcy cases, ordinary first instance courts deal with those cases. However bankruptcy case represent a small fraction of courts' civil caseload. Thus this variability reflects the more general issue of variability in

\footnotetext{
${ }^{4}$ The difference between efficient and inefficient courts within the same border remains very significant and almost identical in magnitude when the length of trials is regressed on a dummy variable for inefficient side of the jurisdiction border controlling for border group fixed effects, on the sample of borders that do not coincide, as shown in column I in Table 1.
} 
Figure 1: Length of bankruptcy proceedings

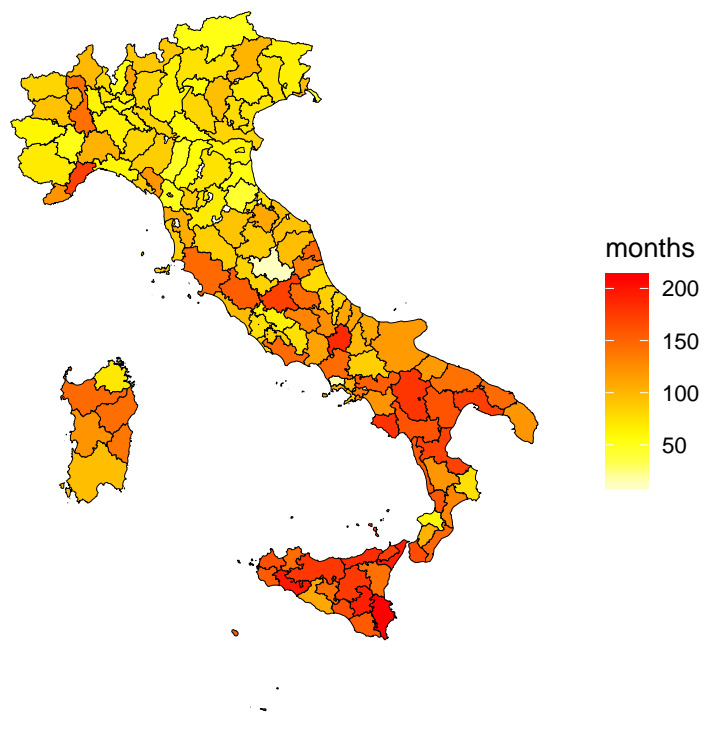

Data from the Ministry of justice. The figure reports the length in months of bankruptcy proceedings closed in the period 2014-2017, by jurisdiction.

the functioning of Italian courts. ${ }^{5}$

A potential threat to the validity of the relevance assumption would come if the parts could choose the court where to file the case (forum shopping). However, differently from other cases, bankruptcy procedures in Italy are automatically assigned to courts according to the geographic location of the legal headquarter of the debtor firm. Therefore there is a tight link between court efficiency in dealing with bankruptcy procedures and firms' headquarter location as forum shopping is de facto impossible.

Another problem would arise if firms choose to locate on the efficient side of the border (self selection). To address this concern we conduct two different exercises, the first on the initial location of the firms headquarter and the second on the pattern in changing the location the legal headquarter using balance sheet data for the period 1995-2011.

Figure 3 reports the kernel density distributions, at the municipality level and across different border groups, of the share of firms with age less than

\footnotetext{
${ }^{5}$ Several factors seem to play a role in determining the differences in the functioning of courts (Bianco et al., 2007; Giacomelli et al., 2017). First, there is a large variation in the demand for court services across the country with much higher litigation rates in the Southern regions. These, in turn, reflect differences in economic development and civic capital and induced demand by lawyers. Second, the decisions on the allocation of resources among courts are highly centralized with limited degree of flexibility to adjust to changes in local demand. Third, there is also significant variation on the supply side. The impossibility for local courts to select and appoint judges, together with the absence of effective courts' management systems and of incentive mechanisms for judges to speed up proceedings, determine some randomness in the distribution of judges' ability and effort among courts.
} 
Figure 2: Distribution of length of trials on both sides of the border

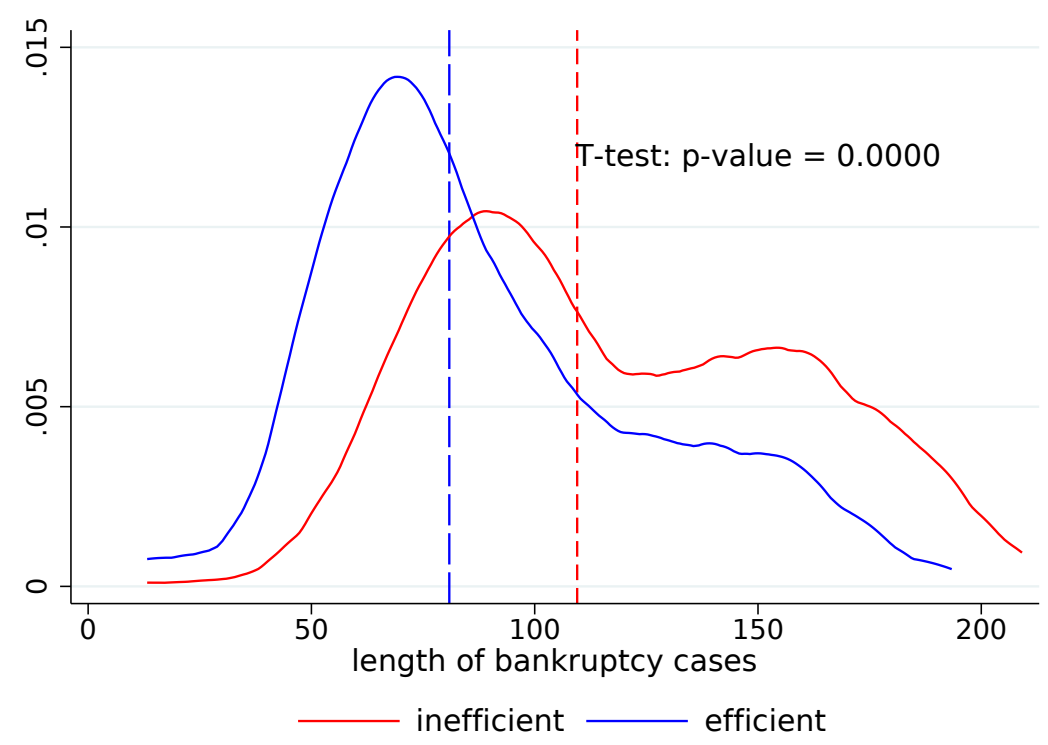

The figures show the Epanechnikov kernel distributions of the length of bankruptcy trials in months across border groups, separated between the efficient (blue) and the inefficient (red) size of the border. The vertical dashed lines show the mean values. All data come from Ministry of Justice and the length of trials is the average of bankruptcy procedures closed between 2014 and 2017.

two years in total number of firms in the municipality. The density of this proxy for the entry rate for the efficient (blue) side of the border is remarkably similar to the one for the inefficient (red) one. A simple T-test, suggests that the difference in the entry rate is not statistically significant, with a p-value of $0,97^{6}$. Even if, from a theoretical point of view, there could be several reasons for court efficiency to affect the location choice of the firms at the beginning their activity, the evidence in Figure 3 suggests that these mechanisms are not empirically relevant and firms location choices are driven by factors different from court efficiency.

Even if firms initial location choice is not driven by court efficiency, firms might decide to change the legal headquarter to a different jurisdiction, based on court efficiency. To check whether this is the case, we analyse the pattern in changing the location of the legal headquarter using balance sheet data for a relatively long period of time (1995-2011). About 5.7\% of firms change location in the sample, and about $70 \%$ of these changes involve a change in the relevant jurisdiction. On average the courts where firms relocate to are slightly more efficient (28 days) than the courts firms move away from, but the difference in not statistically significant. Furthermore very few of these changes of location, about $11 \%$ ( $0.7 \%$ of all firms), are changes from one side to the other of the

\footnotetext{
${ }^{6}$ The difference in entry rate between efficient and inefficient courts within the same border remains very small and not statistically significant when the entry rate at the municipality level is regressed on a dummy variable for inefficient side of the jurisdiction border controlling for border group fixed effects, as shown in column II of Table 1.
} 
Figure 3: Distribution of entry rate on both sides of the border

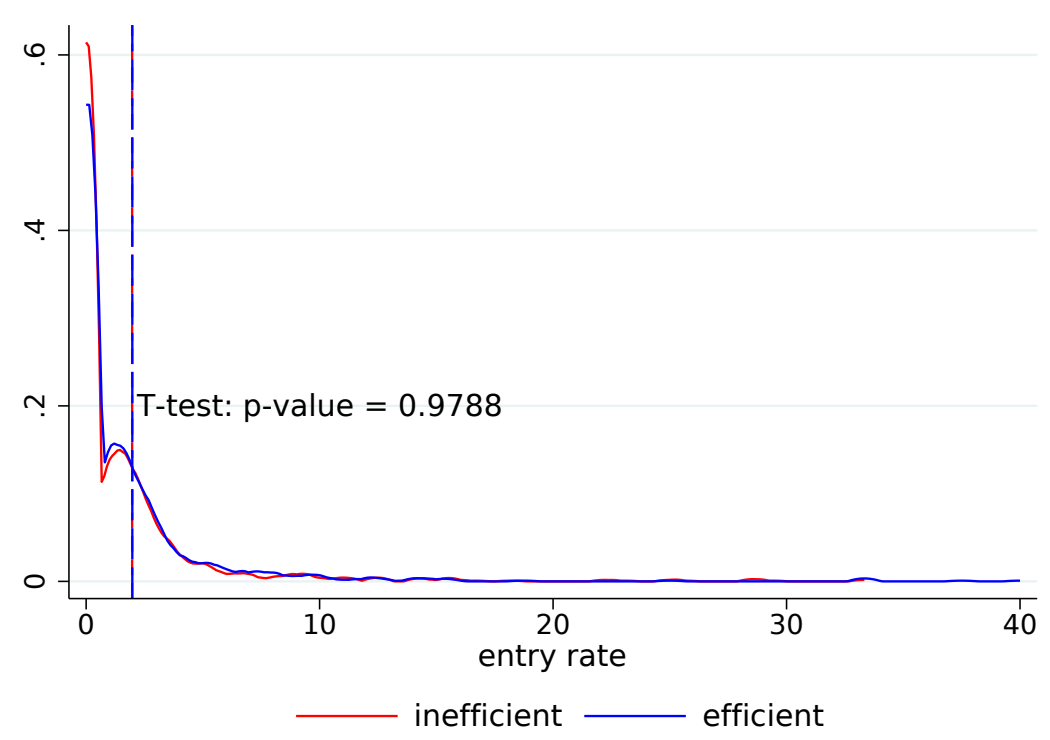

The figures show the Epanechnikov kernel distributions of the entry rate at the municipality level across border groups, separated between the efficient (blue) and the inefficient (red) size of the border. The vertical dashed lines show the mean values. Data come from Cerved Gorup and the Ministry of Justice. The entry rate is defined as the share of firms with age less than two years in the total number of firms in the municipality. The length of trials is the average of bankruptcy procedures closed between 2014 and 2017.

same jurisdiction border, as would be the case if the firm, conditional on other informal institutions, was marginally choosing the location looking at court efficiency. Actually, the firms that change location within the same jurisdiction border tend to move to slightly less efficient courts (16 days, but the difference is not statistically significant).

The exogeneity assumption requires that unobserved local characteristics that might affect bank-firm lending relationships do not vary discontinuously at jurisdiction borders. Until 2012 the territorial organization of the Italian judicial system was based on 165 first instance courts whose jurisdictions were originally established in 1865, right after the unification of Italy. The geography of the post-unification jurisdictions largely resembles that of the former independent states, which partly explains their heterogeneity in size and aggregation criteria.

Although considered as inappropriate and anachronistic by many, the judicial geography remained almost unchanged over the following decades due to strong opposition to reforms at local level. As a result, court jurisdiction boundaries may be considered exogenous to the current economic and financial conditions. They can also be viewed as exogenous to any informal local factors - including social capital, trust, and crime - that may influence the judicial enforcement of national laws at local level, as those factors are expected to change smoothly over space. Court jurisdiction boundaries result from the aggregation of municipal territories, yet they do not systematically match the boundaries of higher administrative levels. However, when courts borders coincide with those 
of other important administrative bodies (e.g. region), a spatial discontinuity not related to judicial efficiency might be introduced posing a threat to our identification strategy. To account for this we concentrate the analysis on those jurisdiction borders that do not coincide with regional boundaries.

A potential concern about the validity of the exogeneity assumption might come from the 2012 reform of "judicial geography" implemented in 2012 by the Italian government, which implied the consolidation of some of the smallest courts, reducing the number from 165 to 140 . However, by aggregating some smaller courts, this reform did not create new, potentially endogenous, jurisdiction borders, but rather eliminated some old exogenous ones. As the empirical analysis only considers firms located at jurisdiction borders that exist after the reform, the recent reform just reduced the number of (exogenous) jurisdictional borders available for the analysis.

Figure 4: Checking exogeneity

(a) Referendum Turnout

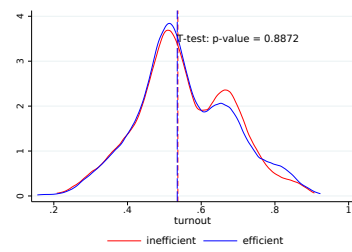

(d) Divorces

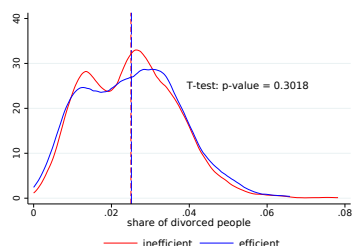

(b) Immigrants

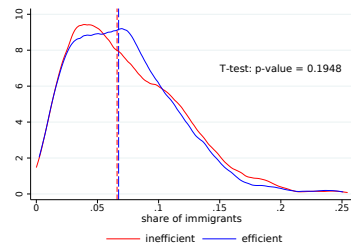

(e) Motorcycles

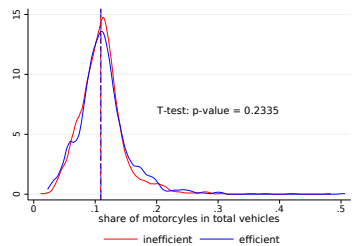

(c) Religious Marriages

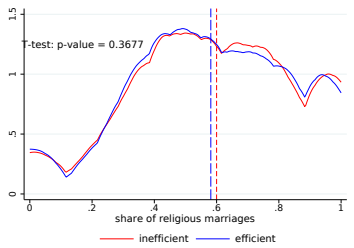

(f) Road Accidents

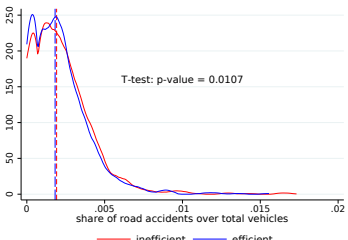

The figures show the Epanechnikov kernel distributions of the relative variables, separated between the efficient (blue) and the inefficient (red) size of the border between different jurisdictions. The vertical dashed lines show the mean values. All variables come from Italian National Institute of Statistics (Istat) for 2019, with the exception of accidents and vehicles registration that are for the year 2018 and of the referendum turnout data that are from the Ministry of Internal Affairs (Ministero del Tesoro). Court efficiency data is from from the Ministry of Justice and the length of trials is the average of bankruptcy procedures closed between 2014 and 2017.

In order to verify empirically the exogeneity assumption ${ }^{7}$, Figure 4 shows the kernel density distributions across different border groups, separated between the efficient (blue) and the inefficient (red) side within the same border group, of six variables that approximates institutional characteristics at the municipality level, that are unlikely to be directly affected by court efficiency: the turnout at the 2020 constitutional referendum, the share of immigrants in total population, the share of religious marriages in total marriages, the share of divorced people,

\footnotetext{
${ }^{7}$ See Giacomelli and Menon (2017) for further discussion of the identification assumptions and for additional evidence to support the exogeneity assumption.
} 
the share of motorcycles in total vehicles and the share or road accidents over total vehicles. Differently from the length of bankruptcy trials, there are no significant differences in these variables around the jurisdiction boundaries, with the exception of road accidents.

To formally test for the differences between the efficient and the inefficient side of the border, we regress, on the sample of borders that do not coincide with regional borders, the six socio-demographic characteristics and the entry rate at the municipal level, as well as our measure of court efficiency at the court level, on a dummy variable for inefficient side of the jurisdiction border, controlling for border group fixed effects. Results for the court efficiency measure, the entry rate and the six socio-demographic characteristics are reported in Table 1. As expected, there is a significant difference between the efficient and the inefficient side of the border (column I). For the entry rate and for almost all the other socio-demographic characteristics, with the exception of road accidents ${ }^{8}$, there does not seem to be a significant difference on either side of the jurisdiction, border, thus supporting the exogeneity assumption. ${ }^{9}$

\subsection{The main dependent variables in the analysis}

When analyzing the effects of court efficiency on bank credit the complexity of the relationships between banks and firms must be addressed. The bank can supply different types of credit (e.g. revolving credit lines, new term loans) and each type of credit contract is in itself a complex one with different characteristics. Furthermore these different features of credit contracts interact in complex ways among themselves (e.g. interest is usually negatively correlated with exposure) and with firms characteristics in ways potentially affected by court efficiency.

To deal with these issues, the paper focuses on few characteristics of bank credit that are relatively less affected. In particular, with respect to the firmbank relationships the analysis addresses only two main aspects: the interest rate and the granted credit on revolving credit lines. The analysis is restricted to revolving credit lines because they are short term, usually unsecured, standardized credit contracts, whose only two terms (granted credit and interest rate) can be changed relatively quickly by the bank. Therefore for this credit contracts it is relatively easy to isolate the effect of court efficiency on the cost and quantity of credit.

Instead, newly issued term loans are more complex objects whose different terms (maturity, size, interest rate, presence of guarantees, covenants) are jointly determined and might be affected simultaneously by court efficiency. Furthermore, in the data, some characteristics of new term loans are not observed (e.g. presence of guarantees) while others are measured in a very coarse way (e.g. maturity). Therefore, the analysis focuses on the aspect of new term loans which is less affected by these concerns, namely the probability of a new term loan being granted to a firm, a measure of the extensive margin of credit.

\footnotetext{
${ }^{8}$ The result on road accidents might be explained by different propensity to denounce a road accident depending on civil court efficiency, which results in a correlation with the length of bankruptcy proceedings if these are correlated with civil courts efficiency.

${ }^{9}$ Furthermore, in all the paper I include a set of these socio-demographic characteristics at the municipality level in the regression analysis, to control for any residual difference. The inclusions of these controls does not affect any of the results.
} 
Table 1: Testing EXogeneity

\begin{tabular}{lcccccccc}
\hline \hline & $(\mathrm{I})$ & $(\mathrm{II})$ & (III) & $(\mathrm{IV})$ & $(\mathrm{V})$ & (VI) & (VII) & (VIII) \\
& court inefficiency & entry rate & turnout & immigrants & religius marriages & divorces & motorcycles & road accidents \\
\hline inefficient & $31.974^{* * *}$ & 0.025 & 0.004 & 0.001 & 0.008 & -0.000 & -0.001 & $0.000^{* *}$ \\
& $(1.999)$ & $(0.155)$ & $(0.003)$ & $(0.001)$ & $(0.008)$ & $(0.000)$ & $(0.001)$ & $(0.000)$ \\
costant & $89.198^{* * *}$ & $1.770^{* * *}$ & $0.548^{* * *}$ & $0.071^{* * *}$ & $0.585^{* * *}$ & $0.025^{* * *}$ & $0.112^{* * *}$ & $0.002^{* * *}$ \\
& $(1.450)$ & $(0.100)$ & $(0.002)$ & $(0.001)$ & $(0.006)$ & $(0.000)$ & $(0.001)$ & $(0.000)$ \\
\hline $\mathrm{N}$ & 384 & 3939 & 3726 & 3748 & 3522 & 3748 & 3748 & 3748 \\
$\mathrm{R}^{2}$ & .91 & .086 & .64 & .556 & .44 & .70 & .57 & .26 \\
\hline$* * * \mathrm{p}<0.01,{ }^{* *} \mathrm{p}<0.05,{ }^{*} \mathrm{p}<0.1$ & & & & & & & \\
\hline \hline
\end{tabular}

The table reports the results of a set of regressions of several dependent variables on an inefficient border dummy which takes value of 1 if the municipality is on the inefficient side of the border. All regressions include jurisdiction border dummy and exclude jurisdiction borders that coincide with the regional borders. The regression in column I is run over variables measured at the jurisdiction level, while all the others exploit variability at the municipality level. In column I the dependent variable is the length of bankruptcy proceedings at the jurisdiction level. In the remaining columns the dependent variable is measured at the municipality level. In column If the dependent variable is the entry rate, measured as the share of firms aged less than two years in the total number of firms. In column III the dependent variable is the is the share of ing constitutional In column VI the dependent variable is the share of divorced people in total population. In column VII the dependent variable is the share of motorcycles in total registered vehicles. Finally, in column VIII the dependent variable is the number of road accidents over registered vehicles. Standard errors are clustered at the court level. 
A second way to measure the effects of court efficiency on the quantity of credit is to measure it with leverage calculated from firm's balance sheets. From firms' balance sheet data a measure firms' investment rate can also be derived, to analyse the real effects of court efficiency.

By lengthening the time to recover bad loans, court inefficiency might increase the stock of NPLs on banks' balance sheet. It could also change the incentives of creditors to repay their obligations (Schiantarelli et al., 2020), thereby affecting the flow of new NPLs. In the analysis, the stock of NPLs is approximated with a dummy variable which takes the value of one if there are some NPLs at the firm-bank match. To analyse the flow of new NPLs the analysis is restricted to firm-bank matches that presented no NPLs in the previous period.

\subsection{The empirical model}

In the empirical analysis we adopt two different specifications depending on the data we use: at the firm-bank match level or at the firm level only.

When using data at the level of firm $(i)$ and bank $(b)$ match the following model is estimated:

$$
Y_{i b t}=\alpha+\beta D_{i}+\sum_{j=1}^{N} \gamma_{j} b_{j i t}+F E s+\delta^{\prime} X_{i b t-1}+\phi^{\prime} W_{i t-1}+\varepsilon_{i b t}
$$

where the dependent variable $Y_{i b t}$ is one of the features of the credit contract between firm $i$ and bank $b$ in year $t$ discussed above (see section 2.2): the interest rate or the granted credit on revolving credit lines and the NPLs dummy.

Our main explanatory variable of interest, $D_{i}$, is the duration of bankruptcy procedures which is relevant for firm $i$, namely the average length, in years, of bankruptcy procedures closed in the period 2014-2017 in the court jurisdiction where firm $i$ has the legal head office. The court efficiency measure is therefore time invariant and the analysis eploits the corss sectional variation only. ${ }^{10}$

The identification strategy is implemented by including in the regression a set of dummies at the level of the border group by year cell, $b_{j i t}$. Each border dummy takes a value of one for all the firms $i$ with legal headquarter in municipalities in the same border group $j$ (i.e. that share the same jurisdiction border) for a given year $t$ : identification arises from variation around the mean within each border group in a given year, and all variables which show little or no variation within the border group are automatically controlled for. There are 280 different border groups in the data. ${ }^{11}$ On average, there are about 10 municipalities in each border (the median is 8) with a minimum of 2 and a maximum of 56 municipalities.

\footnotetext{
${ }^{10}$ The paper does not exploit the potential time series dimension of court efficiency data for two reasons. First, as discussed in Section 2.2, the average length of trials closed in a given year is potentially a noisy variable because in some jurisdictions there is a is based on a limited number of closed proceedings. Second, there is limited time series variation in court efficiency anyway, in particular in bankruptcy given the significant length of bankruptcy procedures (more than 7 years on average).

${ }^{11}$ In order to minimize arbitrariness their composition results from a automated procedure using a Geographic Information System (GIS). See Giacomelli and Menon (2017) for details. I thank Silvia Giacomelli and Carlo Menon for sharing their data on border groups.
} 
All specifications include a set of fixed effects for the region by year, sector of activity by year, bank by year and company's legal status by year cells (FEs). In all specifications controls for firm $\left(W_{i t-1}\right)$ and match $\left(X_{i b t-1}\right)$ characteristics taken in the previous year are included. The match characteristics includes total exposure (in log), a NPLs dummy variable which takes value one if we observe some NPLs at the firm-bank match, the share of used credit to total exposure, the share of short term credit, the share of credit with collateral, the share of credit by the bank. Depending on the main dependent variable, there are controls for other characteristics that might be jointly determined. For example in the specification on the interest rate on credit lines, a control for the average used credit on the line is included.

Firm characteristics include total asset (in log), dafault risk (9 dummy variables one for each of the Cerved SCORE categories), age (5 age dummies, one for each quintile of the age distribution), number of banks, the share of credit by the largest bank, opacity (share of immaterial fixed assets in total fixed assets), potential collateral (share of total fixed assets in total assets), profitability (ROA, measured as EBITDA over total assets), leverage (financial debts over total assets), a "zombie" dummy equal to one if EBITDA is less than interest expenditures, share of liquid to total assets, as well as two time invariant measures of banking competition in the province of the firms legal headquarter (the Herfindahl index of loans distribution by bank in the province and the number of branches in log, both in 2017). In all specification a set of socio-demographic characteristics of the municipality of firm's headquarter is included. ${ }^{12}$

In the analysis of characteristics that change at the firm level, like the probability of a new loan, leverage and investment, the following model is estimated:

$$
Y_{i t}=\alpha+\beta D_{i}+\sum_{j=1}^{N} \gamma_{j} b_{j i t}+F E s++\delta^{\prime} X_{i t-1}+\phi^{\prime} W_{i t-1}+\varepsilon_{i t}
$$

where the firms controls $\left(W_{i t-1}\right)$ are taken from firms' balance sheets and the firm-bank match controls $\left(X_{i t-1}\right)$ are averages at the firm-year level, across different banks. This specification is estimated with two samples: the first includes only firms having credit relationship with banks of at least 30000 Euros; the second all firms with balance sheet information, even those that not observed in the Credit Register data. ${ }^{13}$

The role of firm's default risk The effects of the efficiency in the enforcement of bankruptcy procedures on bank credit depend on the probability that firms are actually involved in a bankruptcy case. If a firm has a very low probability of default and thus to be involved in a bankruptcy proceeding, then its bank credit conditions will be relatively less affected by the efficiency in enforcing bankruptcy law, if they are affected at all (Rodano et al., 2016).

In the data, firms' default risk can be measured by the Cerved SCORE, a proprietary rating that takes values ranging from one (for the safest firm) to nine (for the firm most likely to default). The SCORE is a good predictor of firm's default: Figure 5a shows that the share of firm-bank matches that during

\footnotetext{
${ }^{12}$ These characteristics are population, share of immigrants, share of females in whole population and among immigrants, share of religious marriages, share of divorcees and number of road accidents per person.

${ }^{13}$ In this second case only controls at the firm level are used.
} 
a year experience a new $\mathrm{NPL}^{14}$ is increasing in the SCORE category of the firm. At the same time, Figure 5b reports the average interest rate on revolving credit lines for each SCORE category and shows that the banking sector takes firms' default risk, and in particular the SCORE, into account when offering credit to the firms (see also Rodano et al., 2018).

Figure 5: The SCORE

(a) New NPL

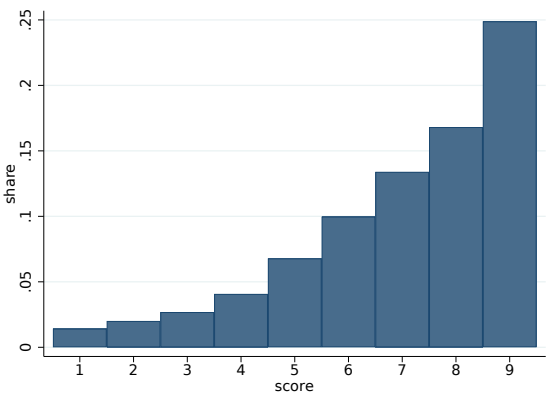

(b) Interest rate

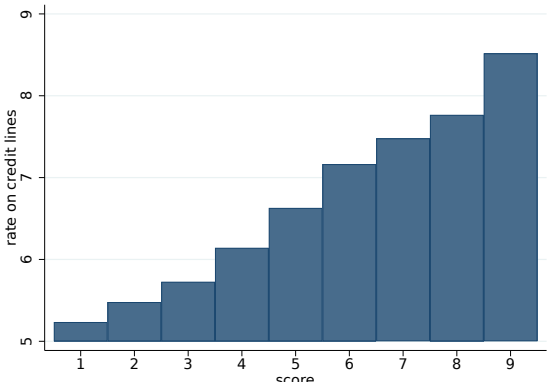

The left panel shows the share of firm-bank matches that enters in NPL status in a given year, for each SCORE category of the firm. The right panel shows the average interest rate on credit lines at the level of firm-bank match, for each SCORE category of the firm. All data comes from Cerved and Credit Register matched dataset used in the main specification of the analysis.

To take into account the potentially different effects of court inefficiency with respect to firm's default risk, in addition to estimates of Equations 1 and 2, we present results where the court inefficiency measure is interacted with firm's default risk in the previous year. Firms' default risk is encoded in a high risk dummy variable, where a firm is classified as "high risk" if the SCORE is above $4 .^{15}$

\section{$3 \quad$ Data and descriptive statistics}

\subsection{Data sources}

This study exploits rich, granular data at the firm-bank level for the universe of Italian corporations with an exposure with the banking sector of at least 30,000 Euros. The analysis is conducted for the years 2015 and 2016, in order to avoid the potential effects of the 2012 reform of judicial geography that reduced the number of courts from 165 to $140 .^{16}$

The data comes from three main sources. The starting point is composed by the balance sheet and profit and losses data for the universe of Italian corporations provided by Cerved Group. Using the unique tax identification code,

\footnotetext{
${ }^{14}$ That is, there was not any NPL in the match in previous year but there is at least some NPL in current year.

${ }^{15}$ Classifying firms in 3 risk categories, following Cerved definition of "safe" (low risk, SCORE less than 5), "vulnerable" (medium risk, SCORE between 4 and 6) and "risky" (high risk, SCORE above 6) firms, yields quantitatively very similar results and are available upon request.

${ }^{16}$ Further details on how we constructed the data set and on the effects of sample selection can be found in Appendix A.
} 
balance sheet data is matched with information from the Central Credit Register (Centrale dei Rischi), a confidential dataset collected by the Bank of Italy as part of its bank supervision duties. ${ }^{17}$ The Credit Register, on a monthly basis, for each borrower whose exposure with the banks exceeds 30,000 Euros, and for each of its lending banks, provides information on financing levels, granted and used, for three categories of instruments: term loans, revolving credit lines, and loans backed by account receivables. The information on term loans is supplemented by other non-price characteristics, such as loan maturity and the presence of real guarantees.

In addition to the information on the quantity of credit, further information on the interest rates, at quarterly frequency for the firm-bank match, comes from Taxia which is part of the Credit Register with information provided by a subset of banks covering more than 80 percent of total bank lending in Italy. More specifically, this data has detailed information on the interest rates that banks charge to individual borrowers on outstanding revolving credit lines together with the average exposure (used credit) on the lines. Furthermore, Taxia has information on interest rate, size and maturity class on all newly issued term loan.

The Cerved Group data includes balance sheet information on the universe of Italian companies, mostly privately held. This dataset provides yearly balancesheet information on assets, revenue, value added, and other characteristics such as location, establishment date, and production sector. In addition, Cerved Group data provides a measure of firms' risk, the SCORE, which is a nine values categorical variable with lower values implying lower risk. In order to merge data from different sources Credit Register data is collapsed at the yearly frequency for each bank-firm match.

Finally, information on the number and duration of bankruptcy procedures at court level is provided by the Ministry of Justice. ${ }^{18}$ The main measure of court efficiency for a given jurisdiction is the average length of bankruptcy procedures closed in that jurisdiction in the period 2014-2017. ${ }^{19}$

\subsection{Descriptive Statistics}

Balance sheet variables The starting point for the analysis is the balance sheet data for the universe of corporations in Italy for the years 2015-2016. From the balance sheet data, several financial and non-financial firms characteristics as well as age, and sector of activity are obtained. Age is the difference between the current year and the year of the firm's establishment. Total Assets are defined on the basis of the Balance Sheet accounts while Net Revenues are taken the profit and loss accounts. Score is the Cerved SCORE the proprietary rating that takes a value ranging from one (for the safest firm) to nine (for firms with highest default risk). Several standard ratios, to be used in the empirical analysis, can be constructed: Leverage is defined as financial debts over assets; ROA is equal to EBITDA over total assets; Liquidity is measured as a the share

\footnotetext{
${ }^{17}$ This data has been used by, among others, Detragiache et al. (2000); Sapienza (2002); Bonaccorsi di Patti and Gobbi (2007) and Cingano et al. (2016).

${ }^{18}$ The data are available on the Ministry of Justice website.

${ }^{19}$ To address the issue of exogeneity, in Section 2, we also exploit data at the municipality level from the National Bureau of Statistics (ISTAT) and from the Ministry of Interior Affairs (Ministero dell'Interno).
} 
Table 2: Descriptive Statistics: Balance Sheet

\begin{tabular}{lcccccc}
\hline \hline & mean & sd & $25^{\text {th }}$ & median & $75^{\text {th }}$ & $\mathrm{N}$ \\
\hline Net Revenues & 7378 & 109182 & 347 & 915 & 2626 & 231543 \\
Age & 16.6 & 13.2 & 7.0 & 13.0 & 24.0 & 228524 \\
Score & 4.62 & 2.07 & 3.00 & 5.00 & 6.00 & 231543 \\
Low Risk (score 1-4) & 0.50 & 0.50 & & & & 231543 \\
Medium Risk (score 5-6) & 0.28 & 0.45 & & & & 231543 \\
High Risk (score 7-9) & 0.22 & 0.41 & & & & 231543 \\
Leverage & 0.18 & 0.22 & 0.00 & 0.09 & 0.30 & 231543 \\
ROA & 0.08 & 0.15 & 0.03 & 0.07 & 0.13 & 231543 \\
Liquidity & 0.10 & 0.14 & 0.01 & 0.04 & 0.14 & 231543 \\
Zombie & 0.25 & 0.43 & & & & 231543 \\
Potential Collateral & 0.19 & 0.23 & 0.02 & 0.09 & 0.29 & 231543 \\
Opacity & 0.05 & 0.11 & 0.00 & 0.00 & 0.04 & 231543 \\
Total Assets & 7832 & 209204 & 408 & 984 & 2725 & 231543 \\
Investment Ratio & 0.41 & 1.17 & 0.01 & 0.07 & 0.29 & 215298 \\
Investment Ratio (net) & 0.21 & 1.03 & -0.09 & -0.02 & 0.08 & 215298 \\
\hline \hline
\end{tabular}

of liquidity in total assets; Zombie is a dummy variable equal to 1 if EBITDA is lower than interest expenditures; Opacity is measured as the share of immaterial fixed assets in total fixed assets; Potential collateral is defined as the share of total fixed assets in total assets. Finally our measure of investment, Investment Ratio, is the ratio of investment expenditures over previous year fixed assets. ${ }^{20}$

Table 3: Balance Sheet: Full and Used samples

\begin{tabular}{lcccc}
\hline \hline & \multicolumn{2}{c}{ Mean } & \multicolumn{2}{c}{ Median } \\
& Full & Used & Full & Used \\
\hline Net revenues & 4314 & 7378 & 479 & 915 \\
Age & 13.7 & 16.6 & 10.0 & 13.0 \\
Score & 4.45 & 4.62 & 4.00 & 5.00 \\
Low Risk (score 1-4) & 0.54 & 0.50 & & \\
Medium Risk (score 5-6) & 0.25 & 0.28 & & \\
High Risk (score 7-9) & 0.22 & 0.22 & & \\
Leverage & 0.13 & 0.18 & 0.00 & 0.09 \\
ROA & 0.08 & 0.08 & 0.08 & 0.07 \\
Liquidity & 0.15 & 0.10 & 0.07 & 0.04 \\
Zombie & 0.25 & 0.25 & & \\
Potential Collateral & 0.17 & 0.19 & 0.07 & 0.09 \\
Opacity & 0.05 & 0.05 & 0.00 & 0.00 \\
Total Assets & 4909 & 7832 & 517 & 984 \\
Investment Ratio & 0.43 & 0.41 & 0.06 & 0.07 \\
\hline \hline Data from Cerved Group balance sheet, for the years \\
2015-2016. The descriptive statistics in the Full columns \\
refer to the whole Cerved Group sample of firms, while \\
those in the Used columns are calculated for the sub- \\
sample of firms that appear also in the Credit Register \\
data and that are located at jurisdiction borders.
\end{tabular}

Given the empirical strategy, the analysis uses a subset of the original sample, consisting of firms with Credit Register data (i.,e. with an exposure of at least 30,000 Euros with the banks) located at the jurisdiction border. Table 2 reports summary statistics of the main variables, in terms of unique firm-year observations for this matched sample. As the variation in firm age suggests, the sample includes not only mature firms but also relatively young firms. Similarly, net revenues vary between 347000 Euros at the bottom quartile of the distribution to over 2.5 million of Euros at the top quartile of the distribution,

\footnotetext{
${ }^{20}$ To reduce the influence of outliers, all ratios are $99 \%$ winsorized.
} 
with an average of above 7 millions. Also total assets distribution is particularly skewed with the average being almost 8 millions euros far higher than the $75^{\text {th }}$ percentile of the distribution. About half of the sample is composed of safe firms (Cerved SCORE less than 5). Mean leverage is about 13\%, but more than half of firms have zero leverage. About $25 \%$ of firms have EBITDA lower than interest expenditures. About $41 \%$ are in municipalities at the border between two jurisdictions.

Table 3 shows mean and median of the main balance sheet variables both in the original sample and the selected one composed of firms with Credit Register data and located at jurisdiction border. ${ }^{21}$ The firms in the selected sample are on average bigger, both in terms of revenues and assets, slightly riskier, more leveraged, with more fixed assets (as a share of total assets) and less liquidity. They are also slightly less productive than those in the original full sample. ${ }^{22}$

Table 4: Descriptive statistics: Credit Register

\begin{tabular}{lcccccc}
\hline \hline & mean & sd & $25^{\text {th }}$ & median & $75^{\text {th }}$ & $\mathrm{N}$ \\
\hline Total Exposure & 845329 & 7196720 & 75697 & 194577 & 514167 & 639253 \\
Share of Used Credit & 0.60 & 0.38 & 0.25 & 0.70 & 1.00 & 639253 \\
Short Term Credit (share) & 0.64 & 0.42 & 0.10 & 0.95 & 1.00 & 639253 \\
Secured Credit (share) & 0.11 & 0.29 & 0.00 & 0.00 & 0.00 & 639253 \\
Share of Biggest Bank & 0.73 & 0.27 & 0.50 & 0.74 & 1.00 & 231543 \\
Number of Banks & 2.76 & 2.65 & 1.00 & 2.00 & 3.00 & 231543 \\
Share of the Bank & 0.36 & 0.33 & 0.10 & 0.24 & 0.54 & 639253 \\
NPL dummy & 0.12 & 0.32 & & & 639253 \\
Share of Discount Credit & 0.34 & 0.38 & 0.00 & 0.15 & 0.71 & 639253 \\
Share of Debt on Credit Lines & 0.21 & 0.31 & 0.00 & 0.06 & 0.25 & 639253 \\
Has Credit Lines & 0.42 & 0.49 & & & & 639253 \\
Used Credit on the Line & 82487 & 1391440 & 1584 & 12622 & 48189 & 200006 \\
Rate on the Credit Line & 7.4 & 3.91 & 4.69 & 6.71 & 9.68 & 200006 \\
Has New Term Loans & 0.24 & 0.43 & & & & 639253 \\
Size of New Term Loans & 1193282 & $3.86 \mathrm{e}+07$ & 75000 & 200000 & 529489 & 115826 \\
Rate on New Term Loans & 3.99 & 2.37 & 2.22 & 3.53 & 5.29 & 115826 \\
Share of Short New Term Loans & 0.42 & 0.47 & 0.00 & 0.00 & 1.00 & 115826 \\
Share of Long New Term Loans & 0.15 & 0.35 & 0.00 & 0.00 & 0.00 & 115826 \\
\hline \hline Data from the Central Credit Register. Statistics for Share Biggest Bank and Number of Banks \\
are calculated at the firm-year level. The shares of firm-bank matches with credit lines (Has Credit \\
Line) and new term loans (Has New Term Loans) are taken considering only banks reporting to \\
the Taxia data set.
\end{tabular}

Credit Register variables After merging the balance sheet data with the Credit Register and selecting only firms whose legal headquarter is located in municipalities at jurisdiction borders, the data set is an unbalanced panel at the firm-bank match and year level. It has about 640000 observations, about 130000 firms matched to 860 banks over two years.

Table 4 reports the descriptive statistics on the main variables used in the analysis for each bank-firm match in a given year. The overall exposure of the

\footnotetext{
${ }^{21}$ The specific sample used depends on the main dependent variable analysed. The full matched balance sheet and Credit Register sample of firms located at jurisdiction borders is used only for the effects on NPLs. In the analysis on the effects on the interest rate and granted amount on revolving credit lines, the sample is restricted to firms with at least one credit line, which is a subset of the firms served by banks in the Taxia dataset. In the analysis of the probability of a new loan the sample is restricted to firms ever appeared in the Taxia dataset. For leverage and investment two samples are used: the full balance sheet sample of firms located at the jurisdiction borders, even when not matched with the Credit Register data, and the sub-sample of those those matched with the Credit Register data.

${ }^{22}$ The main differences in these samples are due to the match with the Credit Register data, see Appendix A for further details.
} 
firm with the bank is measured by Total Exposure defined as the sum of the maximum value between granted and used credit outstanding at the end of the year for each kind of credit (term loans, credit lines and discounts) plus bad loans. On average Total Exposure is about 845,000 euros, and has a rather skewed distribution (the median is slightly less than 200,000 euros). In addition to total exposure, Credit Register data provide information on several other aspects of firm-bank relationship. The Share of Used Credit, measured by the ratio of used credit in total exposure, captures how much "credit space" the firm has with respect to the bank. For the average match, the firm is using about $60 \%$ of total granted credit by the bank. About a quarter of the matches are characterized by no credit space. On average $64 \%$ of the total exposure is short term (Short Term Credit), that is either revolving credit line or with maturity below one year, and $11 \%$ is secured at least partially with real collateral (Secured Credit). On average each firm has credit from 5.3 banks (the median is 4 ) and the biggest bank has a share of $53 \%$ of total credit of the firm. About $12 \%$ of firm-bank matches have some NPLs. Credit lines represent on average $21 \%$ of total bank exposure. Backed loans account for $34 \%$ of total bank financing, and they are mostly used for liquidity purposes.

Table 5: Credit Register variables: Full and Used samples

\begin{tabular}{|c|c|c|c|c|}
\hline & \multicolumn{2}{|c|}{ mean } & \multicolumn{2}{|c|}{ median } \\
\hline & Full & Used & Full & Used \\
\hline Total Exposure & 792215 & 845329 & 189219 & 194577 \\
\hline Share of Used Credit & 0.61 & 0.60 & 0.71 & 0.70 \\
\hline Short Term Credit (share) & 0.63 & 0.64 & 0.90 & 0.95 \\
\hline Secured Credit & 0.12 & 0.11 & 0.00 & 0.00 \\
\hline Share Biggest Bank & 0.73 & 0.73 & 0.74 & 0.74 \\
\hline Number of Banks & 2.75 & 2.76 & 2.00 & 2.00 \\
\hline Share of The Bank & 0.36 & 0.36 & 0.24 & 0.24 \\
\hline NPL dummy & 0.12 & 0.12 & & \\
\hline Share of Discount Credit & 0.33 & 0.34 & 0.01 & 0.15 \\
\hline Share of Debt on Credit Lines & 0.22 & 0.21 & 0.07 & 0.06 \\
\hline Has Credit Lines & 0.42 & 0.42 & & \\
\hline Used Credit on the Line & 90161 & 82487 & 14398 & 12622 \\
\hline Rate on the Credit Line & 7.37 & 7.44 & 6.67 & 6.71 \\
\hline Has New Term Loans & 0.23 & 0.24 & & \\
\hline Size of New Term Loans & 1193509 & 1193282 & 194000 & 200000 \\
\hline Rate on New Term Loans & 3.97 & 3.99 & 3.52 & 3.53 \\
\hline Share of Short New Term Loans & 0.39 & 0.42 & 0.00 & 0.00 \\
\hline Share of Long New Term Loans & 0.16 & 0.15 & 0.00 & 0.00 \\
\hline \multicolumn{5}{|c|}{$\begin{array}{l}\text { Data from the Central Credit Register. The descriptive statistics in the Full } \\
\text { columns refer to the sample of Cerved Group firms that appear also in the } \\
\text { Central Credit Register data. Those in the Used columns refers to the sub- } \\
\text { sample of firms located at jurisdiction borders. Statistics for Share Biggest } \\
\text { Bank and Number of Banks are calculated at the firm-year level. The share of } \\
\text { firm-bank matches for which we observe credit lines (Has Credit Line) and new } \\
\text { term loans (Has New Term Loans) are taken considering only banks reporting } \\
\text { to the Taxia data set. }\end{array}$} \\
\hline
\end{tabular}

As discussed above (see section 2.2) the main price variable in the analysis of bank-firm relationship is the interest credit on the credit lines. This information is available for $42 \%$ of the firm-bank matches. Mean interest rate on the revolving credit lines is about $7.4 \%$ (median $6.7 \%$ ). This interest rate is substantially higher than the interest rate on new term loans, which is about $4 \%$ on average. This might reflect the unsecured nature of credit lines. On average there is a 
new term loan during the year for about $24 \%$ of matches (about $43 \%$ at the firm level), with an average total size of all new loans of more than 1 million. About $40 \%$ of new term loans are short term (less than one year) and $15 \$$ are long term (more than 5 years).

Table 5 shows the differences in mean and median of the Credit Register variables, between the full sample (i.e. firms matched with balance sheet data) and the selected sample which includes only firms located at the jurisdiction border. The differences between the two samples are much smaller than in the balance sheet case, where most of differences were due to the match with the Credit Register.

Table 6: CourT EFFICIENCY

\begin{tabular}{lcccccc}
\hline \hline & mean & sd & $25^{\text {th }}$ & median & $75^{\text {th }}$ & $\mathrm{N}$ \\
\hline length & 107.42 & 42.00 & 74.30 & 98.08 & 143.46 & 140 \\
congestion & 351.39 & 504.68 & 102.50 & 219.00 & 406.00 & 140 \\
\hline \hline
\end{tabular}

Court efficiency The proxy of court efficiency in dealing with bankruptcy cases is the duration of bankruptcy procedures measured as the average time elapsed from the filing of a procedure to its closing in months for all the cases closed in each court from 2014 to 2017 . The choice of using the average length of bankruptcy proceedings over a longer time span (2014-2017) rather than in a single year is due to the risk of very volatile average length that might lead to measurement error, in particular for smaller courts where few procedures are closed in a given year. ${ }^{23}$ Table 6 displays descriptive statistics for the main court efficiency variable (see also Figure 1). The average duration of bankruptcy procedures is extremely high (107 months) with wide differences among courts: it varies from about 74 months at the bottom quartile of the distribution to over 143 months at the top quartile of the distribution. The data allows also to measure congestion at the court level, using as a proxy the total number of bankruptcy proceeding closed in the same period. ${ }^{24}$

\footnotetext{
${ }^{23}$ In order to address the potential concern about reverse causality deriving from using contemporaneous measures of court efficiency and dependent outcomes, I replicated all the analysis in the paper using only the length of procedures closed in 2014-2015. This noisy measure of two court efficiency is highly correlated to the main one used in the paper: their correlation coefficient is 0.91 . The more noisy measure has slightly lower mean, 103.4 months instead of 107,4 months, and is more volatile. Most of the differences in the means and the less than perfect correlation is due to those courts with a low number of cases closed every year. The results of this robustness check, reported in Table 27 in the Appendix B, are qualitatively and in most cases quantitatively similar, to the main results of the paper. When the coefficients differ, they are usually smaller in magnitude, consistently with the hypothesis that this alternative measure might be affected by measurement error.

${ }^{24}$ Length and congestion are strongly negatively correlated at the court level: the regression coefficient of length on congestion in the cross section of courts is negative ad statistically significant (between -0.02 and -0.4 depending on whether we exclude outliers). In a series of robustness exercises — results available upon request — where congestion is included among the controls results are qualitatively and quantitatively unaffected.
} 


\section{Results}

This section reports the main results of the empirical analysis, starting from the interest rates on credit lines (Section 4.1), where we discuss the effects of adopting our empirical strategy, and the importance of addressing omitted variable problem by controlling for local characteristics using "border" dummy variables. Then the effects of court efficiency on the quantity of credit (section 4.2) - granted amount on credit lines, probability of new loan and leverage - as well as on investment (section 4.3) are presented. Finally we analyse the effects of court inefficiency on NPLs (section 4.4).

In all the analysis the main explanatory variable is the length of bankruptcy proceedings in years, which is the measure of court inefficiency. For all dependent variables we present both the baseline results for all firms and the interaction of the court inefficiency measure with the dummy variable for firms with high risk. ${ }^{25}$

\subsection{Interest rate on credit lines}

Table 7: RATES ON CREDIT LINES: IDENTIFICATION STRATEGY

\begin{tabular}{|c|c|c|c|c|c|}
\hline & I & II & III & IV & V \\
\hline \multirow[t]{2}{*}{ court inefficiency } & $0.047^{* *}$ & -0.001 & -0.002 & 0.013 & $0.025^{* * *}$ \\
\hline & & & & & \\
\hline \multicolumn{3}{|l|}{ average credit on line } & $\begin{array}{c}-0.311^{* * *} * \\
(0.006)\end{array}$ & $\begin{array}{c}-0.315^{* * *} \\
(0.007)\end{array}$ & $\begin{array}{c}-0.312^{* * *} * \\
(0.007)\end{array}$ \\
\hline Fixed Effects & $\mathrm{NO}$ & YES & YES & YES & YES \\
\hline Basic Controls & $\mathrm{NO}$ & NO & YES & YES & YES \\
\hline Border Firms Only & $\mathrm{NO}$ & NO & NO & YES & YES \\
\hline Border Dummies & $\mathrm{NO}$ & NO & $\mathrm{NO}$ & $\mathrm{NO}$ & YES \\
\hline $\mathrm{N}$ & 534720 & 534715 & 475942 & 174235 & 174228 \\
\hline $\mathrm{R}^{2}$ & .001 & .108 & .205 & .200 & .205 \\
\hline \multicolumn{6}{|c|}{$* * * \mathrm{p}<0.01,{ }^{* *} \mathrm{p}<0.05,^{*} \mathrm{p}<0.1$} \\
\hline \multicolumn{6}{|c|}{$\begin{array}{l}\text { Dependent variable is net interest rate on outstanding credit lines in the last } \\
\text { quarter of a given year. court inefficiency is the average length of bankruptcy } \\
\text { proceedings, in years; average credit on line is the log of the average amount of } \\
\text { credit on the line; Fixed Effects include fixed effects for region, sector of activity, } \\
\text { bank, legal form interacted with a year dummy; the Basic Controls are lagged } \\
\text { total assets, lagged total exposure, } 9 \text { lagged scone dummy variables, } 5 \text { age dummy } \\
\text { variables, the number of banks and a NPL dummy variable. Standard errors are } \\
\text { clustered at the court by year level. }\end{array}$} \\
\hline
\end{tabular}

Before moving to the main results of the paper, some preliminary specifications (see Table 7 ) show the effects of the sample selection due to considering only firms located at the border between jurisdictions that do not coincide with regional boundaries (columns III vs IV) and the effects of adopting the empirical strategy, confronting firms on either side of the same jurisdiction border controlling for border dummy variables (columns IV vs. V). Column I reports the simple unconditional correlation between court inefficiency and the cost of credit, which is positive and significant. However, as shown in column II, the

\footnotetext{
${ }^{25}$ Our baseline specification includes all the controls. To check whether the result are robust to the inclusion of potentially "bad controls" (see, e.g. Angrist and Pischke, 2008) the same specification is estimated with fewer controls (Basic Controls) including only total asset, total exposure, risk, age and NPL dummies and socio-demographic characteristics, in addition to the fixed effects. The effect of court efficiency is barely affected. However when adding the interaction of court efficiency with firms' risk of default the full set of controls is included to avoid firms' risk capturing the effects of other omitted variables.
} 
Table 8: RATES ON CREDIT LINES

\begin{tabular}{lccc}
\hline \hline & I & II & III \\
\hline court inefficiency & $0.025^{* * *}$ & $0.032^{* * *}$ & $0.021^{* *}$ \\
& $(0.008)$ & $(0.008)$ & $(0.009)$ \\
average credit on line $(\log )$ & $-0.312^{* * *}$ & $-0.331^{* * *}$ & $-0.331^{* * *}$ \\
& $(0.007)$ & $(0.007)$ & $(0.007)$ \\
length $\times$ high risk & & & $0.017^{*}$ \\
& & & $(0.009)$ \\
\hline Fixed Effects & YES & YES & YES \\
Basic Controls & YES & YES & YES \\
Border Firms Only & YES & YES & YES \\
Border Dummies & YES & YES & YES \\
Other Controls & NO & YES & YES \\
\hline $\mathrm{N}$ & 174228 & 174228 & 174228 \\
$\mathrm{R}^{2}$ & .20 & .22 & .22 \\
\hline$* * * \mathrm{p}<0.01,{ }^{* *} \mathrm{p}<0.05,{ }^{*} \mathrm{p}<0.1$ & & \\
\hline \hline
\end{tabular}

Dependent variable is net interest rate on outstanding credit lines in the last quarter of a given year; court inefficiency is the average length of bankruptcy proceedings, in years, for the cases closed in the period 2014-2017; average credit on line is the log of the average amount of credit on the line. Fixed Effects include fixed effects for region, sector of activity, bank, legal form interacted with a year dummy; the Basic Controls are lagged total assets, lagged total exposure, 9 lagged SCORE dummy variables, 5 age dummy variables, the number of banks and a NPL dummy variable as well as socio-demographic controls at the municipality level; Other Controls are lagged controls at the firm level (share of credit by the largest bank, opacity, potential collateral, ROA, leverage, the zombie dummy, liquidity), at the match level (share of used credit, short term credit, secure credit, share of the bank) as well as two time invariant measures of banking competition at the province level. Standard errors are clustered at the court by year level.

raw correlation is not robust to the inclusion of the fixed effects for bank, legal form, region, and sector of production (interacted with a year dummy): the coefficient on court inefficiency becomes negative and not statistically different from zero. Controlling for the amount of used credit and some basic controls (riskiness, size, total exposure, age, presence of NPLs) does not change the coefficient (column III), which remains negative and not statistically significant. Column IV shows the results of the same model of column III estimated on the restricted sample of firms located at the border of jurisdictions, without implementing our identification strategy (i.e. without adding the border dummy variables): the correlation of court inefficiency and the cost of credit becomes positive but not statistically significant. Therefore our sample selection do not have a substantial impact on the estimated relationship between court efficiency and the interest rates, which remains not significant in both samples. However, when we implement our identification strategy by controlling for time-varying unobserved heterogeneity at the geographical level with the inclusion of the interaction of border dummy variables with year dummies (column $\mathrm{V}$ ), the effect of court inefficiency on the cost of credit becomes more than twice stronger and statistically significant. ${ }^{26}$

\footnotetext{
${ }^{26}$ Adding controls for socio-demographic characteristics at the municipality level to the specification in the last column leaves the coefficients unchanged. Table 20 in Appendix B shows that the effects of sample selection and of the application of the identification strategy
} 
Our main results on the interest rates on credit lines are presented in Table 8. Column I reproduces column $\mathrm{V}$ of Table 7 where we include only the set of basic controls. In column II we use the full set of controls. In both cases court inefficiency has a positive and statistically significant correlation with the interest rate on the credit lines. When we control for the wider set of controls the coefficient on court inefficiency is slightly higher. Reducing the length of bankruptcy procedures from the $75^{\text {th }}$ to the $25^{\text {th }}$ percentile of its distribution, from almost 12 years to 6.2 years (about 70 months), would reduce the interest rate on the credit lines by about 14 basis points if we use the estimates in column I (18 basis points if we use the bigger estimate in column II). As the average interest rate in the sample is $7.4 \%$, this reduction corresponds to about $1.9 \%$ $\left(2.5 \%\right.$ for column II) of the average interest rate on the credit lines. ${ }^{27}$

As discussed above (see section 2.3), we expect the effects of court efficiency to be particularly strong for riskier firms that have a significantly higher probability of default and therefore of being subject to a bankruptcy proceeding, in particular in the sort run. In column III we add to the specification in column II the interaction of court inefficiency with a dummy variable for firms with high risk of default (based on balance sheet of previous year). As expected the effects of court inefficiency is stronger for high risk firms: the coefficient of the interaction term is positive and significant. A reduction of the length of bankruptcy proceeding from the $75^{\text {th }}$ to the $25^{\text {th }}$ percentile of the distribution of court efficiency is associated with a reduction in the cost of credit by about 10 basis points for low risk firms and about 22 basis points for high risk firms.

\subsection{Quantity of credit}

After having established the effects of court efficiency on the cost of credit, we analyse its effects on the quantity of credit. Following the discussion in Section 2.2 we focus on two variables about the relationship between bank and firm: the granted amount on the credit lines (at the firm-bank match) to measure the intensive margin of the quantity of credit and the probability of having a new term loan from any bank at the firm level. Finally we look firms' leverage to capture overall firm credit.

Granted amount on the credit lines The results of using the granted amount on the credit lines as the dependent variable in equation 1 are reported in columns I and II of Table 9, where we control for basic and full set of controls respectively. In both cases an increase in the length of trials is associated, in a statistically significant way, with a reduction in the granted credit offered by the same bank at firms with similar characteristics. The coefficients imply that an increase in the length of trials of about 70 months ( 5.8 years) is associated with a reduction in the granted credit for the average match of about $5.7 \%$. Results in column III show that there are significant differences in the effect of court efficiency between safe and risky firms: the same 5.8 years increase in the length of trials is associated with a $3.5 \%$ decrease in granted credit for firms

\footnotetext{
are similar even when controlling for fixed effects only, without any additional control.

${ }^{27}$ Table 21 in Appendix B shows that these results are robust to the inclusion of court congestion among the controls, to the exclusion of granted credit from the regression, as well as that the effect of court efficiency seems to be non-linear.
} 
Table 9: Granted AMOUnt on the CREDIT Lines

\begin{tabular}{lccc}
\hline \hline & I & II & III \\
\hline court inefficiency & $-0.010^{* * *}$ & $-0.009^{* * *}$ & $-0.006^{* *}$ \\
& $(0.003)$ & $(0.003)$ & $\begin{array}{c}(0.003) \\
\text { length } \times \text { high risk }\end{array}$ \\
& & & $-0.006^{* * *}$ \\
& & & $(0.002)$ \\
\hline Fixed Effects & YES & YES & YES \\
Basic Controls & YES & YES & YES \\
Border Firms Only & YES & YES & YES \\
Border Dummies & YES & YES & YES \\
Other Controls & NO & YES & YES \\
\hline $\mathrm{N}$ & 352457 & 352457 & 352457 \\
$\mathrm{R}^{2}$ & .32 & .36 & .36 \\
\hline$* * * \mathrm{p}<0.01,{ }^{* *} \mathrm{p}<0.05,{ }^{*} \mathrm{p}<0.1$ & \\
\hline \hline
\end{tabular}

Dependent variable is the credit amount, in log, on revolving credit line at the firm-bank match level; court inefficiency is the average length of bankruptcy proceedings, in years, for the cases closed in the period 2014-2017; Fixed Effects include fixed effects for region, sector of activity, bank, legal form interacted with a year dummy; the Basic Controls are lagged total assets, 9 lagged SCORE dummy variables, 5 age dummy variables, the number of banks and a NPL dummy variable, as well as socio-demographic controls at the municipality level; Other Controls are lagged controls at the firm level (share of credit by the largest bank, opacity, potential collateral, ROA, leverage, the zombie dummy, liquidity), at the match level (share of used credit, short term credit, secure credit, share of the bank) as well as two time invariant measures of banking competition at the province level. Standard errors are clustered at the court by year level.

with low default risk and with a $6.9 \%$ decrease for high risk ones. ${ }^{28}$.

Probability of new loan In order to analyse the effects of court efficiency on the extensive margin of credit Equation 2 is estimated with dependent variable a dummy variable equal to 1 if in a given year the firm receives a new term loan granted by any of its banks. ${ }^{29}$ The resulting estimates are reported in Table 10. The first two columns show the estimates of the model with few (column I) and all controls (column II): there is no significant correlation of court efficiency with the probability of getting a new loan for the average firm: the coefficient of the length of trials in negative but not statistically significant. However, as shown in column III, there is a significant and negative association between court inefficiency and the probability of getting a new loan for firms with high risk of default. An increase in the length of bankruptcy proceeding from the $25^{\text {th }}$ to the $75^{\text {th }}$ percentile of its distribution, is associated with a decrease in the probability of receiving a new loan for the high risk firm of about 1.7 percentage points. The share of firm for which we observe a new loan in a given year in the sample is on average about $43 \%$, with differences according to firms' risk, from

\footnotetext{
${ }^{28}$ In the results of Table 9 we do not include previous year exposure at the firm-bank match among the controls. The results in a specification which includes it are almost identical, even quantitatively, as shown in Table 22 in Appendix B.

${ }^{29}$ The model is estimated with a linear probability model, considering only those firms who ever appear in the Taxia dataset.
} 
Table 10: Probability of NEW LOAN

\begin{tabular}{lccc}
\hline \hline & I & II & III \\
\hline court inefficiency & -0.001 & -0.002 & 0.002 \\
& $(0.001)$ & $(0.001)$ & $\begin{array}{c}(0.001) \\
-0.006^{* * *} \\
\text { length } \times \text { high risk }\end{array}$ \\
& & & $(0.001)$ \\
\hline Fixed Effects & YES & YES & YES \\
Basic Controls & YES & YES & YES \\
Border Firms Only & YES & YES & YES \\
Border Dummies & YES & YES & YES \\
Other Controls & NO & YES & YES \\
\hline $\mathrm{N}$ & 145226 & 145226 & 145226 \\
$\mathrm{R}^{2}$ & .15 & .17 & .17 \\
\hline$* * * \mathrm{p}<0.01,{ }^{* *} \mathrm{p}<0.05,{ }^{*} \mathrm{p}<0.1$ & \\
\hline \hline
\end{tabular}

Dependent variable is a dummy variable equal to 1 if a new term loan is granted to the firm in the relevant year; court inefficiency is the average length of bankruptcy proceedings, in years, for the cases closed in the period 2014-2017; Fixed Effects includes fixed effects for region, sector of activity, legal form interacted with a year dummy; the Basic Controls are lagged total assets, the lagged total exposure of the firm, 9 lagged SCORE dummy variables, 5 age dummy variables, the number of banks and a NPL dummy variable, as well as socio-demographic controls at the municipality level; Other Controls includes lagged controls at the firm level: the share of credit by the largest bank, opacity, potential collateral, ROA, leverage, the zombie dummy, liquidity, share of used credit, short term credit, secure credit as well as two time invariant measures of banking competition at the province level. Standard errors are clustered at the court by year level.

$45 \%$ for safe firms to $41 \%$ for high risk firms. ${ }^{30}$

Leverage To analyse the overall effect of court efficiency on firm debt, including both the intensive and the extensive margin, we also estimate Equation 2 using firm's leverage as dependent variable. Table 11 reports the estimates of the effects of court efficiency on leverage obtained using the sample of firms with both balance sheet and Credit Register data and controlling also for bank credit data (aggregated at the firm level). ${ }^{31}$ For the average firm (columns I, II) the effect of court inefficiency on leverage is negative but small and not statistically significant. When we interact the length of bankruptcy cases with the dummy variable for high risk firms (column III), we find that high court efficiency is associated with higher leverage for risky firms and lower leverage for safe ones. Using the results from column III, a reduction of the length of bankruptcy proceeding from the $75^{\text {th }}$ to the $25^{\text {th }}$ percentile of its distribution is associated with

\footnotetext{
${ }^{30}$ The more appropriate measure of the extensive margin of credit is the probability of getting a new loan at the firm level rather than at the firm bank-level. If a firm gets a new loan from one of its bank and no new loan from some other banks, the latter measure would be a more inaccurate measure.

${ }^{31}$ Table 23 in Appendix B reports results obtained when using the sample of firms with only balance sheet data and the results for the matched sample but without controlling for Credit Register data. Results are almost identical, the few differences coming from controlling for Credit Register variables rather than using different samples.
} 
Table 11: LeverAGE

\begin{tabular}{lccc}
\hline \hline court inefficiency & I & II & III \\
& 0.000 & -0.000 & $0.001^{* *}$ \\
length $\times$ high risk & & & $\begin{array}{c}(0.001) \\
-0.003^{* * *} \\
\end{array}$ \\
& & & $(0.001)$ \\
\hline Fixed Effects & YES & YES & YES \\
Basic Controls & YES & YES & YES \\
Border Firms Only & YES & YES & YES \\
Border Dummies & YES & YES & YES \\
Other Controls & NO & YES & YES \\
\hline $\mathrm{N}$ & 201737 & 201737 & 201737 \\
$\mathrm{R}^{2}$ & .17 & .20 & .20 \\
\hline$* * * \mathrm{p}<0.01,{ }^{* *} \mathrm{p}<0.05,{ }^{*} \mathrm{p}<0.1$ & \\
\hline \hline
\end{tabular}

Dependent variable is firm leverage; court inefficiency is the average length of bankruptcy proceedings, in years, for the cases closed in the period 2014-2017; Fixed Effects includes fixed effects for region, sector of activity, and legal form interacted with a year dummy; the Basic Controls are lagged total assets, , 9 lagged score dummy variables, 5 age dummy variables, lagged total exposure of the firm, the number of banks and a NPL dummy variable as well as sociodemographic controls at the municipality level; Other Controls include lagged controls at the firm level: opacity, potential collateral, ROA, leverage, the zombie dummy, liquidity, the share of credit by the largest bank, the share of used credit, short term credit, secure credit average (the Credit Register variables are averaged at the firm level), as well as two time invariant measures of banking competition at the province level. Standard errors are clustered at the court by year level.

a decrease of leverage of 0.6 percentage points for safe firms, and an increase of 1.2 points for high risk firms (average leverage id about $17 \%$ in the sample).

\subsection{Investment}

To analyse the real effects of court efficiency we estimate Equation 2 with firm level data, using as dependent variable the investment rate measured as investment in fixed assets over previous period fixed assets. Table 12 shows the results for investment rate obtained using, similarly to leverage, the sample of firms with both balance sheet and Credit Register data and controlling also for bank credit data (aggregated at the firm level). ${ }^{32}$ Court inefficiency has a negative but not statistically significant effect on investment activity of the average firms (columns I, II). However interacting court inefficiency with firm's risk dummy variables, more inefficient courts are associated with lower investment activity for riskier firms (columns III) while the effect on investment by safe firms is positive, but small and not statistically significant. Using the results from column III a reduction of the length of bankruptcy proceeding of about

\footnotetext{
${ }^{32}$ Results obtained when using the sample of firms with only balance sheet data and those for the matched sample but without controlling for Credit Register data are reported in Table 24 in Appendix B. Results are even stronger than in the baseline specification, and the main differences come from controlling for Credit Register variables rather than using different samples.
} 
Table 12: InVESTMENT RATE

\begin{tabular}{lccc}
\hline \hline & I & II & III \\
\hline court inefficiency & -0.002 & -0.002 & -0.000 \\
& $(0.002)$ & $(0.002)$ & $(0.002)$ \\
length $\times$ high risk & & & $-0.003^{*}$ \\
& & & $(0.002)$ \\
\hline Fixed Effects & YES & YES & YES \\
Basic Controls & YES & YES & YES \\
Border Firms Only & YES & YES & YES \\
Border Dummies & YES & YES & YES \\
Other Controls & NO & YES & YES \\
\hline $\mathrm{N}$ & 198388 & 198388 & 198388 \\
$\mathrm{R}^{2}$ & .035 & .06 & .066 \\
\hline$* * * \mathrm{p}<0.01,{ }^{* *} \mathrm{p}<0.05,^{*} \mathrm{p}<0.1$ & \\
\hline \hline
\end{tabular}

Dependent variable is firm investment rate; court inefficiency is the average length of bankruptcy proceedings, in years, for the cases closed in the period 2014-2017; Fixed Effects includes fixed effects for region, sector of activity, and legal form interacted with a year dummy; the Basic Controls are lagged total assets, , 9 lagged SCORE dummy variables, 5 age dummy variables ,lagged total exposure of the firm, the number of banks and a NPL dummy variable as well as socio-demographic controls at the municipality level; Other Controls include lagged controls at the firm level: opacity, potential collateral, ROA, leverage, the zombie dummy, liquidity, the share of credit by the largest bank, the share of used credit, short term credit, secure credit average (the Credit Register variables are averaged at the firm level), as well as two time invariant measures of banking competition at the province level. Standard errors are clustered at the court by year level.

70 months is associated with an increase in the investment rate of 1.7 percentage points for high risk firms against an average investment rate of about $4.9 \%$ (5.8\% for riskier firms).

\subsection{Non Performing Loans}

Where bankruptcy procedures are less efficient the time to recover NPLs is longer and, mechanically, the stock of NPLs increases. Furthermore, theoretical and empirical literature suggests that where court are less efficient, borrowers might have stronger incentives to default (e.g. Schiantarelli et al., 2020), thus increasing the flow of new NPLs. This, in turn, might affect the willingness and possibility of bank to extend credit, in particular given the new rules for timely provisioning and write-off practices related to non-performing loans (so called calendar provisioning) recently introduced by the ECB (ECB, 2018) and the European Commission (EC, 2018). While we cannot verify the actual time the bad loans stay on banks' balance sheet, we can analyse whether court efficiency is associated with a higher stock of NPLs and with a stronger flow of new ones.

To analyse the effects of court inefficiency on the stock of NPLs we estimate Equation 1 using as dependent variable a dummy equal to 1 if the match is characterized by at least some NPLs. Conditioning on the sample of matches with no NPLs in the previous year, we can also investigate whether court inefficiency affects the flow of new positions with NPLs. 
Table 13: Non PERforming LoAns

\begin{tabular}{l|ccc|ccc}
\hline \hline & \multicolumn{3}{|c|}{ Stock } & \multicolumn{3}{c}{ Flow } \\
& I & II & III & IV & V & VI \\
\hline court inefficiency & $0.003^{* * *}$ & $0.002^{* * *}$ & -0.001 & $0.001^{* * *}$ & 0.000 & $-0.001^{* *}$ \\
& $(0.001)$ & $(0.001)$ & $(0.001)$ & $(0.000)$ & $(0.000)$ & $(0.000)$ \\
length $\times$ high risk & & & $0.005^{* * *}$ & & & $0.003^{* * *}$ \\
& & & $(0.001)$ & & & $(0.001)$ \\
\hline Fixed Effects & YES & YES & YES & YES & YES & YES \\
Basic Controls & YES & YES & YES & YES & YES & YES \\
Border Firms Only & YES & YES & YES & YES & YES & YES \\
Border Dummies & YES & YES & YES & YES & YES & YES \\
Other Controls & NO & YES & YES & NO & YES & YES \\
\hline $\mathrm{N}$ & 506950 & 506950 & 506950 & 463100 & 463100 & 463100 \\
$\mathrm{R}^{2}$ & .12 & .16 & .16 & .06 & .07 & .08 \\
\hline$* * * \mathrm{p}<0.01, * * \mathrm{p}<0.05, * \mathrm{p}<0.1$ & \multicolumn{3}{c}{} \\
\hline \hline
\end{tabular}

Dependent variable is a dummy variable equal to 1 if there is at least one NPL between the bank and the firm. In columns IV, V e VI, the estimating sample is restricted to firm-bank matches for which there were no NPLs in previous year. court inefficiency is the average length of bankruptcy proceedings, in years, for the cases closed in the period 2014-2017. Fixed Effects includes fixed effects for region, sector of activity, bank, legal form interacted with a year dummy. The Basic Controls are lagged total assets, lagged total exposure, 9 lagged SCORE dummy variables, 5 age dummy variables and the number of banks, as well as socio-demographic controls at the municipality level; Other Controls are lagged controls at the firm level (share of credit by the largest bank, opacity, potential collateral, ROA, leverage, the zombie dummy, liquidity), at the match level (share of used credit, short term credit, secure credit, share of the bank) as well as two time invariant measures of banking competition at the province level. Standard errors are clustered at the court by year level.

The results for the stock of NPLs are reported in the first 3 columns of Table 13. Where courts are more inefficient and take more time to solve bankruptcy cases there is a higher probability of observing a firm-bank match with some NPLs (columns I and II). The effect is due only to high risk firms (column III). Reducing the length of bankruptcy trials from the $75^{\text {th }}$ to the $25^{\text {th }}$ percentile of its distribution we would observe a reduction of 1.7 percentage points (1.2 if we take the estimated coefficient in column II) in the share of firm-bank matches with some NPLs on average (2.3 percentage points less for high risk firms and banks while no significant effects for the safe firms). On average about $12 \%$ of firm-bank matches have some NPLs (17\% of those involving an high risk firm).

The results for the flow of new matches with NPLs are reported in columns IV, V and VI of Table 13. Lower court efficiency has a positive but not robust effect on the flow of new matches with some NPLs (columns IV and V). By interacting court inefficiency with the risk dummy variables (column VI), we find that the effects of court inefficiency on the probability of observing a new match with some NPLs between safe firms and banks is negative (i.e. court efficiency increase the likelihood of new matches with NPLs) while it is positive for high risk firms matches with banks. The usual though experiment of improving court efficiency would be associated with an increase in the probability of observing a match between a safe firm and a bank that becomes a NPLs match in a given year by about 0.6 percentage points. The same improvement in court efficiency would reduce the probability of observing a match between a high risk firm and a bank that becomes a NPLs match in a given year by about 1.2 percentage points . On average about $7 \%$ of all matches enters in the NPLs status in a given year (about $10.4 \%$ of those involving an high risk firm). ${ }^{33}$.

${ }^{33}$ As shown in Table 25 in Appendix B, using the share of NPLs in total exposure instead 


\section{Concluding remarks}

Court efficiency is often at the core of the policy debate, in particular in Italy, but to better design policy reforms, a clear understanding of how court efficiency affects firms and banks decisions is needed. However, evidence on the extent of the effects of court enforcement on credit supply and the economy, as well as the relevant channels, is scant, mostly because of the challenge of isolating the effects of judicial enforcement from other formal and informal institutions that may affect bank lending to firms. By isolating the effects of court enforcement on credit conditions, this paper presents several novel features of how bank credit and firms' decisions react to court efficiency. Banks seem to use credit quantities rather than prices as the main margin of adjustment in the supply of credit. Moreover they seem to tilt credit conditions significantly in favor of low risk firms when court efficiency worsens. These results are of particular relevance from the policy perspective: not only court inefficiency is associated with a worsening of credit conditions for all firms, but it also induces a misallocation of credit against riskier, but potentially more innovative, activities.

There are at least two different channels, which are likely to interact in practice, for court efficiency to affect firms relationship with the banking system.

This paper provides some evidence that two distinct, but potentially interacting, transmission channels from court enforcement and credit supply. On one side, court efficiency directly affects the present value of how much the bank recover in the event of default and thus the expected value for the bank of lending to the firm, which in turn affects the credit condition the bank is willing to make to the firm. On the other side, when courts are inefficient the balance sheets of the banks will be loaded by bigger stock of NPLs which in turn might affect lending practices by the banks.

While providing a substantial first step in understanding these complex issues, this paper does not address several important aspects of the transmission channels from court efficiency to firms and banks decisions. How do the two channels interact? What are the margins of adjustment most used used by the banks (price, quantities, covenants, guarantees)? How does banks' behaviour in response to improvement in court efficiency depends on their balance sheet, the the regulatory framework and the degree of competition in credit markets? What are the distributive and allocative effects of improving court efficiency? The quest for the answers to all these questions is left for future research. However, given the complexity of the issues, the reduced form empirical approach adopted in this paper has limited scope to address them. A more structural approach that uses careful theoretical modeling to exploit the richness of data on the phenomenon is most likely the way to go (see e.g. Crawford et al., 2018; González-Torres and Rodano, 2020).

of a simple dummy yields very similar results; in the great majority of cases (about $94 \%$ of observations) the share of NPLs is either zero or one. The results are also similar when we use a "bad loans" dummy instead of a NPL dummy, as shown in Table 26. 


\section{References}

Matteo Accornero, Piergiorgio Alessandri, Luisa Carpinelli, and Alberto Maria Sorrentino. Non-performing loans and the supply of bank credit: evidence from Italy. Questioni di Economia e Finanza (Occasional Papers) 374, Bank of Italy, Economic Research and International Relations Area, March 2017.

Joshua D. Angrist and Jorn-Steffen Pischke. Mostly Harmless Econometrics: An Empiricist's Companion. Princeton University Press, 2008.

Kee-Hong Bae and Vidhan K. Goyal. Creditor rights, enforcement, and bank loans. Journal of Finance, 64(2):823 - 860, 2009. ISSN 00221082.

Magda Bianco, Silvia Giacomelli, Cristina Giorgiantonio, Giuliana Palumbo, and Bruna Szego. La durata (eccessiva) dei procedimenti civili in italia: offerta, domanda o rito? Rivista di Politica Economica, 47(9-10):3 - 53, 2007.

Sandra E. Black. Do better schools matter? Parental valuation of elementary education. Quarterly Journal of Economics, 114(2):577 - 599, 1999. ISSN 00335533 .

Emilia Bonaccorsi di Patti. Weak institutions and credit availability: the impact of crime on bank loans. Questioni di Economia e Finanza (Occasional Papers) 52, Bank of Italy, Economic Research and International Relations Area, July 2009.

Emilia Bonaccorsi di Patti and Giorgio Gobbi. Winners or losers? the effects of banking consolidation on corporate borrowers. Journal of Finance, 62(2): 669-695, 2007.

Matthieu Chemin. Does court speed shape economic activity? evidence from a court reform in india. Journal of Law, Economics, and Organization, 28(3): 460-485, 2012.

Federico Cingano, Francesco Manaresi, and Enrico Sette. Does Credit Crunch Investment Down? New Evidence on the Real Effects of the Bank-Lending Channel. The Review of Financial Studies, 29(10):2737-2773, 062016.

Gregory S. Crawford, Nicola Pavanini, and Fabiano Schivardi. Asymmetric information and imperfect competition in lending markets. American Economic Review, 108(7):1659-1701, July 2018.

Enrica Detragiache, Paolo Garella, and Luigi Guiso. Multiple versus single banking relationships: Theory and evidence. Journal of Finance, 55(3):11331161, 062000.

Simeon Djankov, Caralee McLiesh, and Andrei Shleifer. Private credit in 129 countries. Journal of Financial Economics, 84(2):299 - 329, 2007.

EC. proposal for a regulation of the European Parliament and of the Council on amending Regulation (EU) No 575/2013 as regards minimum loss coverage for nonperforming exposures . Technical Report COM(2018)134, European Commission -FISMA (DG Financial Stability, Financial Services and Capital Markets Union), March 2018. 
ECB. Addendum to the ECB Guidance to banks on non-performing loans: supervisory expectations for prudential provisioning of non-performing exposures. Technical report, European Central Bank - Banking Supervision, March 2018.

Daniela Fabbri. Law enforcement and firm financing: Theory and evidence. Journal of the European Economic Association, 8(4):776 - 816, 2010.

Silvia Giacomelli and Carlo Menon. Does weak contract enforcement affect firm size? Evidence from the neighbour's court. Journal of Economic Geography, 17(6):1251-1282, 102017.

Silvia Giacomelli, Sauro Mocetti, Giuliana Palumbo, and Giacomo Roma. Civil justice in Italy: recent trends. Questioni di Economia e Finanza (Occasional Papers) 401, Bank of Italy, Economic Research and International Relations Area, October 2017.

Guzmán González-Torres and Giacomo Rodano. Court efficiency and aggregate productivity: the credit channel. Temi di discussione (Economic working papers) 1287, Bank of Italy, Economic Research and International Relations Area, July 2020.

Luigi Guiso, Paola Sapienza, and Luigi Zingales. The role of social capital in financial development. American Economic Review, 94(3):526 - 556, 2004.

Oliver Hart and John Moore. Default and renegotiation: A dynamic model of debt. The Quarterly Journal of Economics, 113(1):1-41, 1998.

Thomas J. Holmes. The effect of state policies on the location of manufacturing: Evidence from state borders. Journal of Political Economy, 106(4):667 - 705, 1998.

Tullio Jappelli, Marco Pagano, and Magda Bianco. Courts and banks: Effects of judicial enforcement on credit markets. Journal of Money, Credit and Banking, 37(2):223-44, 2005.

Rafael La Porta, Florencio Lopez-de Silanes, Andrei Shleifer, and Robert Vishny. Legal determinants of external finance. Journal of Finance, 52(3): 1131 - 1150, 1997.

Luc Laeven and Giovanni Majnoni. Does judicial efficiency lower the cost of credit? Journal of Banking \& Finance, 29(7):1791 - 1812, 2005.

Josh Lerner and Antoinette Schoar. Does legal enforcement affect financial transactions? the contractual channel in private equity. Quarterly Journal of Economics, 120(1):223 - 246, 2005.

Jacopo Ponticelli and Leonardo S. Alencar. Court enforcement, bank loans, and firm investment: Evidence from a bankruptcy reform in brazil. The Quarterly Journal of Economics, 131(3):1365-1413, 032016.

Jun Qian and Philip E. Strahan. How laws and institutions shape financial contracts: The case of bank loans. Journal of Finance, 62(6):2803 - 2834, 2007. 
Giacomo Rodano, Nicolas Serrano-Velarde, and Emanuele Tarantino. Bankruptcy law and bank financing. Journal of Financial Economics, 120 (2):363-382, 2016.

Giacomo Rodano, Nicolas Serrano-Velarde, and Emanuele Tarantino. Lending Standards over the Credit Cycle. The Review of Financial Studies, 31(8): 2943-2982, 042018.

Paola Sapienza. The effects of banking mergers on loan contracts. Journal of Finance, 57(1):329-367, 022002.

Fabio Schiantarelli, Massimiliano Stacchini, and Philip E. Strahan. Bank quality, judicial efficiency, and loan repayment delays in italy. The Journal of Finance, 75(4):2139-2178, 2020.

Sujata Visaria. Legal reform and loan repayment: The microeconomic impact of debt recovery tribunals in india. American Economic Journal: Applied Economics, 1(3):59-81, September 2009. 


\section{Appendices}

\section{A Data appendix}

The starting point for the dataset is the balance sheet for the universe of Italian corporations from Cerved Group for the years 2014-2016. We do some preliminary cleaning by dropping: $i$ ) inactive firms (firms with no revenues, no assets ${ }^{34}$, no SCORE variable); ii) firms in some sectors ${ }^{35}$ and firms with no information on sector of activity. This leaves us with information about slightly less than 600.000 firms over two years.

Table 14 reports descriptive statistics for the full sample ${ }^{36}$.

Table 14: Descriptive statistics: Balance Sheet

\begin{tabular}{lcccccc}
\hline \hline & mean & sd & $25^{\text {th }}$ & median & $75^{\text {th }}$ & $\mathrm{N}$ \\
\hline score & 4.45 & 2.19 & 3.00 & 4.00 & 6.00 & 1032845 \\
low risk & 0.54 & 0.50 & & & & 1032845 \\
medium risk & 0.25 & 0.43 & & & & 1032845 \\
high risk & 0.22 & 0.41 & & & & 1032845 \\
leverage & 0.13 & 0.21 & 0.00 & 0.00 & 0.21 & 1032845 \\
roa & 0.08 & 0.20 & 0.02 & 0.08 & 0.15 & 1032845 \\
liquidity & 0.15 & 0.19 & 0.01 & 0.07 & 0.21 & 1032845 \\
zombie & 0.25 & 0.43 & & & & 1032845 \\
potential collateral & 0.17 & 0.22 & 0.02 & 0.07 & 0.25 & 1032845 \\
opacity & 0.05 & 0.11 & 0.00 & 0.00 & 0.03 & 1032845 \\
total assets & 4909 & 182012 & 176 & 517 & 1595 & 1032845 \\
investment ratio & 0.43 & 1.24 & 0.00 & 0.06 & 0.29 & 892111 \\
investment ratio (net) & 0.21 & 1.09 & -0.11 & -0.02 & 0.07 & 892111 \\
used & 0.37 & 0.48 & & & & 1032845 \\
is in CR & 0.61 & 0.49 & & & & 1032845 \\
\hline \hline
\end{tabular}

Then we match balance sheet information with bank credit information from the Credit Register information if available: about $61 \%$ of observation are matched with the Credit Register data. These firms are on average bigger, slightly riskier, more leveraged, with more fixed assets (as a share of total assets) and less liquidity, and slightly less productive than those not present in the Credit Register (see Table 15).

Once we keep only those firms with both balance sheet data and Credit Register data, we are left with slightly more than 350000 distinct firms over two years. Table 16 reports detailed descriptive statistics for balance sheet for firms with data in the Credit Register at the firm-year level. The data from the Credit Register are at the firm bank year level.

Our identification strategy forces us to consider only firms located at the jurisdiction border. Furthermore we consider only borders that do not coincide with regional borders as there might be other economic and socio-political factors other than court efficiency that change discontinuously at these particular borders. Once we keep only firms with both balance sheet data and Credit Reg-

\footnotetext{
${ }^{34}$ We drop also firms with total assets equal to 1 euro.

${ }^{35}$ The excluded sectors are: "Agriculture, forestry and fishing" (NACE Rev. 2, Section A), "Mining and quarrying" (Section B), "Financial and insurance activities" (Section K), "Real estate activities" (Section L) and non private services (Sections N, O, P, Q, R, S, T)

36 All ratios are winsorized at the $1 \%$ level.
} 
Table 15: Balance Sheet: With and without CR

\begin{tabular}{lcccc}
\hline \hline & \multicolumn{2}{c}{ mean } & \multicolumn{2}{c}{ median } \\
& Not CR & CR & Not CR & CR \\
\hline score & 4.18 & 4.61 & 4.00 & 5.00 \\
low risk & 0.60 & 0.50 & & \\
medium risk & 0.19 & 0.28 & & \\
high risk & 0.21 & 0.22 & & \\
leverage & 0.06 & 0.18 & 0.00 & 0.09 \\
roa & 0.09 & 0.08 & 0.09 & 0.07 \\
liquidity & 0.22 & 0.10 & 0.14 & 0.04 \\
zombie & 0.25 & 0.25 & & \\
potential collateral & 0.13 & 0.20 & 0.04 & 0.10 \\
opacity & 0.05 & 0.04 & 0.00 & 0.00 \\
total assets & 978 & 7448 & 171 & 965 \\
investment ratio & 0.50 & 0.40 & 0.05 & 0.06 \\
investment ratio (net) & 0.23 & 0.20 & -0.01 & -0.02 \\
used & 0.37 & 0.37 & & \\
\hline \hline
\end{tabular}

Table 16: Balance SheEt: firms with CR

\begin{tabular}{lcccccc}
\hline \hline & mean & $\mathrm{sd}$ & $25^{\text {th }}$ & median & $75^{\text {th }}$ & $\mathrm{N}$ \\
\hline score & 4.61 & 2.06 & 3.00 & 5.00 & 6.00 & 627555 \\
low risk & 0.50 & 0.50 & & & & 627555 \\
medium risk & 0.28 & 0.45 & & & & 627555 \\
high risk & 0.22 & 0.41 & & & & 627555 \\
leverage & 0.18 & 0.22 & 0.00 & 0.09 & 0.30 & 627555 \\
roa & 0.08 & 0.15 & 0.03 & 0.07 & 0.13 & 627555 \\
liquidity & 0.10 & 0.14 & 0.01 & 0.04 & 0.14 & 627555 \\
zombie & 0.25 & 0.43 & & & & 627555 \\
potential collateral & 0.20 & 0.24 & 0.02 & 0.10 & 0.30 & 627555 \\
opacity & 0.04 & 0.10 & 0.00 & 0.00 & 0.03 & 627555 \\
total assets & 7448 & 233045 & 402 & 965 & 2639 & 627555 \\
investment ratio & 0.40 & 1.16 & 0.01 & 0.06 & 0.28 & 584077 \\
investment ratio (net) & 0.20 & 1.02 & -0.09 & -0.02 & 0.08 & 584077 \\
used & 0.37 & 0.48 & & & & 627555 \\
\hline \hline
\end{tabular}

ister and whose headquarter is located in a municipality at one of those border we are left with about 130000 firms over two years. However this further selection of the sample does not seem to alter in a significant way the characteristics of the firms in the sample with respect to both balance sheet variables (Table 18) and Credit Register variables (19) in Appendix B. 
Table 17: Credit Register variables

\begin{tabular}{|c|c|c|c|c|c|c|}
\hline & mean & $\mathrm{sd}$ & $25^{\text {th }}$ & median & $75^{\text {th }}$ & $\mathrm{N}$ \\
\hline total exposure & 811881 & 7286013 & 75229 & 190418 & 503213 & 1726490 \\
\hline share of used credit & 0.61 & 0.38 & 0.25 & 0.71 & 1.00 & 1726490 \\
\hline short term credit (share) & 0.64 & 0.43 & 0.08 & 0.92 & 1.00 & 1726490 \\
\hline secured credit & 0.11 & 0.29 & 0.00 & 0.00 & 0.00 & 1726490 \\
\hline share biggest bank & 0.53 & 0.26 & 0.32 & 0.48 & 0.70 & 1726490 \\
\hline number of banks & 5.29 & 4.86 & 2 & 4 & 7 & 1726490 \\
\hline NPL dummy & 0.12 & 0.33 & & & & 1726490 \\
\hline has credit lines & 0.31 & 0.46 & & & & 1726490 \\
\hline used credit on the line & 87330 & 1186363 & 1734 & 13740 & 50761 & 542298 \\
\hline rate on the credit line & 7.39 & 3.87 & 4.68 & 6.68 & 9.57 & 542298 \\
\hline has new term loans & 0.17 & 0.38 & & & & 1726490 \\
\hline size of new term loans & 1193421 & $3.04 \mathrm{e}+07$ & 75000 & 198854 & 501453 & 299017 \\
\hline rate on new term loans & 3.98 & 2.37 & 2.22 & 3.53 & 5.27 & 299017 \\
\hline share of short term loans & 0.40 & 0.47 & & & & 299017 \\
\hline share of long term loans & 0.16 & 0.35 & & & & 299017 \\
\hline
\end{tabular}

Table 18: BAlAnce SheET: BORDer AND NON BORDER

\begin{tabular}{lcccc}
\hline \hline & \multicolumn{2}{c}{ mean } & \multicolumn{2}{c}{ median } \\
& Non border & Border & Non border & Border \\
\hline score & 4.61 & 4.62 & 4.00 & 5.00 \\
low risk (score 1-4) & 0.50 & 0.50 & & \\
medium risk (score 5-6) & 0.28 & 0.28 & & \\
high risk (score 7-9) & 0.22 & 0.22 & & \\
leverage & 0.18 & 0.18 & 0.09 & 0.09 \\
roa & 0.08 & 0.08 & 0.07 & 0.07 \\
liquidity (over total assets) & 0.10 & 0.10 & 0.04 & 0.04 \\
zombie (ebit i interest exp.) & 0.25 & 0.25 & & \\
fixed assets (over total assets) & 0.21 & 0.19 & 0.10 & 0.09 \\
intangible assets (over total assets) & 0.04 & 0.05 & 0.00 & 0.00 \\
total assets & 7223 & 7832 & 954 & 984 \\
investment ratio & 0.39 & 0.41 & 0.06 & 0.07 \\
investment ratio (net) & 0.20 & 0.21 & -0.02 & -0.02 \\
\hline \hline
\end{tabular}

Table 19: Credit Register VARIABles: BORDER AND NON BORDER

\begin{tabular}{lcccc}
\hline \hline & \multicolumn{2}{c}{ mean } & \multicolumn{2}{c}{ median } \\
& Non border & Border & Non border & Border \\
\hline total exposure & 792215 & 845329 & 189219 & 194577 \\
share of used credit & 0.61 & 0.60 & 0.71 & 0.70 \\
short term credit (share) & 0.63 & 0.64 & 0.90 & 0.95 \\
secured credit & 0.12 & 0.11 & 0.00 & 0.00 \\
share biggest bank & 0.53 & 0.53 & 0.48 & 0.48 \\
number of banks & 0.12 & 0.12 & 0.00 & 0.00 \\
NPL dummy & 5.29 & 5.30 & 4 & 4 \\
has credit lines & 0.31 & 0.31 & & \\
used credit on the line & 90161 & 82487 & 14398 & 12622 \\
rate on the credit line & 7.37 & 7.44 & 6.67 & 6.71 \\
has new term loans & 0.17 & 0.18 & & \\
size of new term loans & 1193509 & 1193282 & 194000 & 200000 \\
rate on new term loans & 3.97 & 3.99 & 3.52 & 3.53 \\
share of short term loans & 0.39 & 0.42 & & \\
share of long term loans & 0.16 & 0.15 & & \\
\hline \hline
\end{tabular}




\section{B Additional tables}

Table 20: IDENTIFICATION STRATEGY - NO CONTROLS

\begin{tabular}{lcccc}
\hline \hline & I & II & III & IV \\
\hline court inefficiency & $0.047^{* *}$ & -0.001 & 0.013 & $0.031^{* * *}$ \\
& $(0.018)$ & $(0.009)$ & $(0.01100)$ & $(0.00902)$ \\
\hline Fixed Effects & NO & YES & YES & YES \\
Border Firms Only & NO & NO & YES & YES \\
Border Dummies & NO & NO & NO & YES \\
\hline $\mathrm{N}$ & 534720 & 534715 & 196252 & 196246 \\
$\mathrm{R}^{2}$ & .001 & .108 & .10 & .11 \\
\hline${ }^{* *} \mathrm{p}<0.01,{ }^{* *} \mathrm{p}<0.05,{ }^{*} \mathrm{p}<0.1$ & & \\
\hline \hline
\end{tabular}

Dependent variable is net interest rate on outstanding credit lines in the last quarter of a given year. court inefficiency is the average length of bankruptcy proceedings, in years, for the cases closed in the period 2014-2017. Fixed Effects includes fixed effects for region, sector of activity, bank, legal form interacted with a year dummy.

Table 21: RoBUSTNESS CHECK INTEREST RATES ON CREDIT LINES

\begin{tabular}{|c|c|c|c|c|c|c|}
\hline & \multicolumn{2}{|c|}{ Congestion } & \multicolumn{2}{|c|}{ No Credit } & \multicolumn{2}{|c|}{ Non linear } \\
\hline & I & II & III & IV & $\mathrm{V}$ & VI \\
\hline court inefficiency & $\begin{array}{c}0.025^{* * *} \\
(0.008)\end{array}$ & $\begin{array}{c}0.032^{* * *} * \\
(0.008)\end{array}$ & $\begin{array}{c}0.027 * * * \\
(0.008)\end{array}$ & $\begin{array}{c}0.034^{* * *} * \\
(0.008)\end{array}$ & & \\
\hline average credit on line & $\begin{array}{c}-0.312 * * * \\
(0.007)\end{array}$ & $\begin{array}{c}-0.331 * * * \\
(0.007)\end{array}$ & & & $\begin{array}{r}-0.312 * * * \\
(0.00657)\end{array}$ & $\begin{array}{r}-0.331 * * * \\
(0.00679)\end{array}$ \\
\hline $2^{\text {nd }}$ terc. of inefficiency & & & & & $\begin{array}{c}0.035 \\
(0.046)\end{array}$ & $\begin{array}{c}0.059 \\
(0.047)\end{array}$ \\
\hline $3^{\text {rd }}$ terc. of inefficiency & & & & & $\begin{array}{c}0.155^{* *} \\
(0.072)\end{array}$ & $\begin{array}{c}0.201^{* * *} \\
(0.066)\end{array}$ \\
\hline Fixed Effects & YES & YES & YES & YES & YES & YES \\
\hline Basic Controls & YES & YES & YES & YES & YES & YES \\
\hline Border Firms Only & YES & YES & YES & YES & YES & YES \\
\hline Border Dummies & YES & YES & YES & YES & YES & YES \\
\hline Other Controls & $\mathrm{NO}$ & YES & $\mathrm{NO}$ & YES & $\mathrm{NO}$ & YES \\
\hline $\mathrm{N}$ & 174228 & 174228 & 174228 & 174228 & 174228 & 174228 \\
\hline $\mathrm{R}^{2}$ & .20 & .22 & .16 & .17 & .20 & .22 \\
\hline $\begin{array}{l}\text { Dependent variable is ne } \\
\text { court inefficiency is the } \\
\text { in the period 2014-2017. } \\
\text { line. Fixed Effects inclu } \\
\text { with a year dummy. th } \\
\text { Score dummy variables, } \\
\text { as well as socio-demogra } \\
\text { at the firm level (share o } \\
\text { zombie dummy, liquidity } \\
\text { share of the bank) as we } \\
\text { level. Standard errors a } \\
\text { court by year level. }\end{array}$ & $\begin{array}{l}\text { interest rat } \\
\text { average len } \\
\text { average cr } \\
\text { les fixed ef } \\
\text { Basic Cor } \\
\text { age dumm } \\
\text { hic control } \\
\text { credit by th } \\
\text { at the ma } \\
\text { as two tir } \\
\text { clustered }\end{array}$ & $\begin{array}{l}\text { on outstan } \\
\text { th of bank } \\
\text { it on line } \\
\text { cts for regi } \\
\text { rols are lag } \\
\text { variables, } \\
\text { at the mun } \\
\text { largest ban } \\
\text { h level (sh. } \\
\text { invariant } \\
\text { the court }\end{array}$ & $\begin{array}{l}\text { d total as } \\
\text { number } \\
\text { ality leve } \\
\text { opacity, p } \\
\text { of used c } \\
\text { easures of } \\
\text { year leve }\end{array}$ & $\begin{array}{l}\text { s in the la } \\
\text { lings, in y } \\
\text { he averag } \\
\text { ctivity, be } \\
\text { ts, lagged } \\
\text { banks an } \\
\text { Other Co } \\
\text { ential coll } \\
\text { dit, short } \\
\text { anking co } \\
\text { tandard }\end{array}$ & $\begin{array}{l}\text { quarter of } \\
\text { rs, for the } \\
\text { amount of } \\
\mathrm{K} \text {, legal for } \\
\text { otal expos } \\
\text { NPL dum } \\
\text { rols are la } \\
\text { eral, ROA, } \\
\text { m credit, } \\
\text { etition at } \\
\text { ors are clu }\end{array}$ & $\begin{array}{l}\text { given year. } \\
\text { ases closed } \\
\text { edit on the } \\
\text { interacted } \\
\text { e, } 9 \text { lagged } \\
\text { ay variable, } \\
\text { ed controls } \\
\text { everage, the } \\
\text { cure credit, } \\
\text { he province } \\
\text { ered at the }\end{array}$ \\
\hline
\end{tabular}


Table 22: Granted CREdit (CONTROLLING FOR PASt EXPOSURE)

\begin{tabular}{lccc}
\hline \hline & I & II & III \\
\hline court inefficiency & $-0.010^{* * *}$ & $-0.011^{* * *}$ & $-0.007^{* * *}$ \\
& $(0.003)$ & $(0.003)$ & $\begin{array}{c}(0.003) \\
\text { length } \times \text { high risk }\end{array}$ \\
& & & $-0.006^{* * *}$ \\
& & & $(0.002)$ \\
\hline Fixed Effects & YES & YES & YES \\
Basic Controls & YES & YES & YES \\
Border Firms Only & YES & YES & YES \\
Border Dummies & YES & YES & YES \\
Other Controls & NO & YES & YES \\
\hline $\mathrm{N}$ & 352457 & 352457 & 352457 \\
$\mathrm{R}^{2}$ & .39 & .42 & .42 \\
\hline$* * * \mathrm{p}<0.01, * * \mathrm{p}<0.05,{ }^{*} \mathrm{p}<0.1$ & \\
\hline \hline
\end{tabular}

Dependent variable is the credit amount, in log, on revolving credit line at the firm-bank match level; court inefficiency is the average length of bankruptcy proceedings, in years, for the cases closed in the period 20142017; Fixed Effects include fixed effects for region, sector of activity, bank, legal form interacted with a year dummy; the Basic Controls are lagged total assets, 9 lagged SCORE dummy variables, 5 age dummy variables, the number of banks and a NPL dummy variable, as well as socio-demographic controls at the municipality level; Other Controls are lagged controls at the firm level (share of credit by the largest bank, opacity, potential collateral, roa, leverage, the zombie dummy, liquidity), at the match level (share of used credit, short term credit, secure credit, share of the bank) as well as two time invariant measures of banking competition at the province level. Standard errors are clustered at the court by year level. 
Table 23: Leverage (DifFEREnt SAMPles AND CONTROLS)

\begin{tabular}{l|ccc|ccc}
\hline \hline & \multicolumn{3}{|c|}{ Cerved only } & \multicolumn{3}{c}{ Cerved and Credit Register } \\
& I & II & III & IV & V & VI \\
\hline court inefficiency & -0.000 & -0.000 & $0.002^{* * *}$ & 0.000 & -0.000 & $0.002^{* * *}$ \\
& $(0.000)$ & $(0.000)$ & $(0.001)$ & $(0.000)$ & $(0.000)$ & $(0.001)$ \\
length $\times$ high risk & & & $-0.004^{* * *}$ & & & $-0.004^{* * *}$ \\
& & & $(0.001)$ & & & $(0.001)$ \\
\hline Fixed Effects & YES & YES & YES & YES & YES & YES \\
Basic Controls & YES & YES & YES & YES & YES & YES \\
Border Firms Only & YES & YES & YES & YES & YES & YES \\
Border Dummies & YES & YES & YES & YES & YES & YES \\
Other Controls & NO & YES & YES & NO & YES & YES \\
\hline $\mathrm{N}$ & 329710 & 329710 & 329710 & 211912 & 211912 & 211912 \\
$\mathrm{R}^{2}$ & .16 & .18 & .18 & .15 & .16 & .16 \\
\hline$* * * \mathrm{p}<0.01,{ }^{* *} \mathrm{p}<0.05, * \mathrm{p}<0.1$ & \multicolumn{5}{c}{} \\
\hline
\end{tabular}

Dependent variable is firm leverage; court inefficiency is the average length of bankruptcy proceedings, in years, for the cases closed in the period 2014-2017; Fixed Effects includes fixed effects for region, sector of activity, and legal form interacted with a year dummy; the Basic Controls, lagged total assets, , 9 lagged score dummy variables, 5 age dummy variables as well as socio-demographic controls at the municipality level; Other Controls include lagged controls at the firm level: opacity, potential collateral, roa, leverage, the zombie dummy, liquidity as well as two time invariant measures of banking competition at the province level. Standard errors are clustered at the court by year level.

Table 24: Investment RAte (DiffEREnt SAMPles AND CONTROLS)

\begin{tabular}{l|ccc|ccc}
\hline \hline & \multicolumn{3}{|c|}{ Cerved only } & \multicolumn{3}{c}{ Cerved and Credit Register } \\
& I & II & III & IV & V & VI \\
\hline court inefficiency & -0.001 & -0.000 & 0.002 & -0.001 & -0.001 & 0.002 \\
& $(0.002)$ & $(0.002)$ & $(0.002)$ & $(0.002)$ & $(0.002)$ & $(0.003)$ \\
length $\times$ high risk & & & $-0.005^{* *}$ & & & $-0.006^{* * *}$ \\
& & & $(0.002)$ & & & $(0.002)$ \\
\hline Fixed Effects & YES & YES & YES & YES & YES & YES \\
Basic Controls & YES & YES & YES & YES & YES & YES \\
Border Firms Only & YES & YES & YES & YES & YES & YES \\
Border Dummies & YES & YES & YES & YES & YES & YES \\
Other Controls & NO & YES & YES & NO & YES & YES \\
\hline $\mathrm{N}$ & 316887 & 316887 & 316887 & 208252 & 208252 & 208252 \\
$\mathrm{R}^{2}$ & .03 & .06 & .06 & .05 & .076 & .08 \\
\hline$* * \mathrm{p}<0.01,{ }^{* *} \mathrm{p}<0.05,{ }^{*} \mathrm{p}<0.1$ & \multicolumn{5}{|c}{} \\
\hline
\end{tabular}

Dependent variable is firm investment rate; court inefficiency is the average length of bankruptcy proceedings, in years, for the cases closed in the period 2014-2017; Fixed Effects includes fixed effects for region, sector of activity, and legal form interacted with a year dummy; the Basic Controls, lagged total assets, , 9 lagged SCORE dummy variables, 5 age dummy variables as well as socio-demographic controls at the municipality level; Other Controls include lagged controls at the firm level: opacity, potential collateral, roa, leverage, the zombie dummy, liquidity as well as two time invariant measures of banking competition at the province level. Standard errors are clustered at the court by year level. 
Table 25: Share of Non Performing LoAns in total exposure

\begin{tabular}{|c|c|c|c|c|c|c|}
\hline & \multicolumn{3}{|c|}{ Stock } & \multicolumn{3}{|c|}{ Flow } \\
\hline & I & II & III & IV & V & VI \\
\hline $\begin{array}{l}\text { court inefficiency } \\
\text { length } \times \text { high risk }\end{array}$ & $\begin{array}{c}0.002^{* * *} \\
(0.000)\end{array}$ & $\begin{array}{c}0.002^{* * *} \\
(0.000)\end{array}$ & $\begin{array}{c}-0.000 \\
(0.001) \\
0.004 * * * \\
(0.000)\end{array}$ & $\begin{array}{l}-0.000 \\
(0.000)\end{array}$ & $\begin{array}{l}-0.000 \\
(0.000)\end{array}$ & $\begin{array}{c}-0.001^{* * *} \\
(0.000) \\
0.001^{* * *} \\
(0.000)\end{array}$ \\
\hline Fixed Effects & YES & YES & YES & YES & YES & YES \\
\hline Basic Controls & YES & YES & YES & YES & YES & YES \\
\hline Border Firms Only & YES & YES & YES & YES & YES & YES \\
\hline Border Dummies & YES & YES & YES & YES & YES & YES \\
\hline Other Controls & NO & YES & YES & $\mathrm{NO}$ & YES & YES \\
\hline $\mathrm{N}$ & 506950 & 506950 & 506950 & 463100 & 463100 & 463100 \\
\hline $\mathrm{R}^{2}$ & .12 & .19 & .19 & .06 & .07 & .08 \\
\hline \multicolumn{7}{|c|}{$\begin{array}{l}\text { Dependent variable is the share of NPLs in total assets. In columns IV, V e VI, the estimating } \\
\text { sample is restricted to firm-bank matches for which there were no NPLs in previous year. court } \\
\text { inefficiency is the average length of bankruptcy proceedings, in years, for the cases closed in the } \\
\text { period 2014-2017. Fixed Effects includes fixed effects for region, sector of activity, bank, legal } \\
\text { form interacted with a year dummy. The Basic Controls are lagged total assets, lagged total } \\
\text { exposure, } 9 \text { lagged sconE dummy variables, } 5 \text { age dummy variables and the number of banks, as } \\
\text { well as socio-demographic controls at the municipality level; Other Controls are lagged controls } \\
\text { at the firm level (share of credit by the largest bank, opacity, potential collateral, roa, leverage, } \\
\text { the zombie dummy, liquidity), at the match level (share of used credit, short term credit, secure } \\
\text { credit, share of the bank) as well as two time invariant measures of banking competition at the } \\
\text { province level. Standard errors are clustered at the court by year level. }\end{array}$} \\
\hline
\end{tabular}

Table 26: BAD LOANS

\begin{tabular}{|c|c|c|c|c|c|c|}
\hline & \multicolumn{3}{|c|}{ Stock } & \multicolumn{3}{|c|}{ Flow } \\
\hline & $\mathrm{I}$ & II & III & IV & $\mathrm{V}$ & VI \\
\hline \multirow{2}{*}{$\begin{array}{l}\text { court inefficiency } \\
\text { length } \times \text { high risk }\end{array}$} & $\begin{array}{c}0.001^{* * *} * \\
(0.000)\end{array}$ & $\begin{array}{c}0.001^{* * *} \\
(0.000)\end{array}$ & $\begin{array}{c}0.000 \\
(0.000)\end{array}$ & $\begin{array}{c}0.000^{* * *} \\
(0.000)\end{array}$ & $\begin{array}{c}0.000^{* * *} \\
(0.000)\end{array}$ & $\begin{array}{c}-0.000 \\
(0.000)\end{array}$ \\
\hline & & & $\begin{array}{c}0.002^{* * *} * \\
(0.000)\end{array}$ & & & $\begin{array}{c}0.001^{* * *} * \\
(0.000)\end{array}$ \\
\hline Fixed Effects & YES & YES & YES & YES & YES & YES \\
\hline Basic Controls & YES & YES & YES & YES & YES & YES \\
\hline Border Firms Only & YES & YES & YES & YES & YES & YES \\
\hline Border Dummies & YES & YES & YES & YES & YES & YES \\
\hline Other Controls & NO & YES & YES & $\mathrm{NO}$ & YES & YES \\
\hline $\mathrm{N}$ & 506950 & 506950 & 506950 & 502747 & 502747 & 502747 \\
\hline $\mathrm{R}^{2}$ & .07 & .16 & .16 & .02 & .04 & .04 \\
\hline \multicolumn{7}{|c|}{$* * * \mathrm{p}<0.01,{ }^{* *} \mathrm{p}<0.05,{ }^{*} \mathrm{p}<0.1$} \\
\hline \multicolumn{7}{|c|}{$\begin{array}{l}\text { Dependent variable is a dummy variable equal to } 1 \text { if the firm-bank matches experience some bad } \\
\text { loans. In columns IV, V e VI, the estimating sample is restricted to firm-bank matches for which } \\
\text { there were no bad loans in previous year. court inefficiency is the average length of bankruptcy } \\
\text { proceedings, in years, for the cases closed in the period 2014-2017. Fixed Effects includes fixed } \\
\text { effects for region, sector of activity, bank, legal form interacted with a year dummy. The Basic } \\
\text { Controls are lagged total assets, lagged total exposure, } 9 \text { lagged score dummy variables, } 5 \\
\text { age dummy variables and the number of banks, as well as socio-demographic controls at the } \\
\text { municipality level; Other Controls are lagged controls at the firm level (share of credit by the } \\
\text { largest bank, opacity, potential collateral, roa, leverage, the zombie dummy, liquidity), at the } \\
\text { match level (share of used credit, short term credit, secure credit, share of the bank) as well as } \\
\text { two time invariant measures of banking competition at the province level. Standard errors are } \\
\text { clustered at the court by year level. }\end{array}$} \\
\hline
\end{tabular}


Table 27: RoBUstness: NOISY LENGTH OF TRIALS

\begin{tabular}{l|ccccccc}
\hline \hline & I & II & III & IV & V & VI & VII \\
& Rates & Quant. & New Loan & Lev. & Inv. & NPL & NPL (flow) \\
\hline noisy court inefficiency & 0.010 & -0.003 & 0.002 & $0.002^{* * *}$ & -0.001 & $-0.002^{* * *}$ & $-0.001^{* * *}$ \\
& $(0.009)$ & $(0.003)$ & $(0.001)$ & $(0.001)$ & $(0.002)$ & $(0.001)$ & $(0.000)$ \\
length $\times$ high risk & $0.014^{*}$ & $-0.006^{* * *}$ & $-0.005^{* * *}$ & $-0.002^{* * *}$ & -0.003 & $0.005^{* * *}$ & $0.002^{* * *}$ \\
& $(0.008)$ & $(0.002)$ & $(0.001)$ & $(0.001)$ & $(0.002)$ & $(0.001)$ & $(0.001)$ \\
\hline Fixed Effects & YES & YES & YES & YES & YES & YES & YES \\
Basic Controls & YES & YES & YES & YES & YES & YES & YES \\
Border Firms Only & YES & YES & YES & YES & YES & YES & YES \\
Border Dummies & YES & YES & YES & YES & YES & YES & YES \\
Other Controls & YES & YES & YES & YES & YES & YES & YES \\
\hline $\mathrm{N}$ & 174228 & 352457 & 145226 & 201737 & 198388 & 506950 & 463100 \\
$\mathrm{R}^{2}$ & .22 & .36 & .16 & .20 & .07 & .16 & .08 \\
\hline$* * * \mathrm{p}<0.01,{ }^{* *} \mathrm{p}<0.05,{ }^{*} \mathrm{p}<0.1$
\end{tabular}

The table reports the results of column III of main tables of the paper, when using the measure of noisy court inefficiency which is the average length of bankruptcy proceedings, in years, for the cases closed in the period 2014-2015. In column I the main dependent variable is net interest rate on outstanding credit lines in the last quarter of a given year. In column II the dependent variable is the credit amount, in log, on revolving credit lines. In column II the dependent variable is a dummy variable equal to 1 if a new term loan is granted to the firm in the relevant year. In column IV the dependent variable is firm leverage. In column $V$ the dependent variable is firm investment rate. In column VI the dependent variable is the share of NPLs in total assets. In column VII dependent variable is the share of NPLs in total assets and the sample is restricted to firm-bank matches for which there were no NPLs in
previous year. Standard errors are clustered at the court by year level. 


\section{RECENTLY PUBLISHED “TEMI” (*)}

N.1301 - A quantitative analysis of distortions in managerial forecasts, by Yueran Ma, Tiziano Ropele, David Sraer and David Thesmar (November 2020).

N.1302 - Bargaining power and the Phillips curve: a micro-macro analysis, by Marco J. Lombardi, Marianna Riggi and Eliana Viviano (November 2020).

N. 1303 - The effects of structural reforms: Evidence from Italy, by Emanuela Ciapanna, Sauro Mocetti and Alessandro Notarpietro (November 2020).

N. 1304 - Consumption and Wealth: New Evidence from Italy, by Riccardo De Bonis, Danilo Liberati, John Muellbauer and Concetta Rondinelli (November 2020).

N. 1305 - Do details matter? An analysis of the Italian personal income tax, by Martino Tasso (November 2020).

N.1306 - Effects of eligibility for central bank purchases on corporate bond spreads, by Taneli Mäkinen, Fan Li, Andrea Mercatanti and Andrea Silvestrini (November 2020).

N. 1307 - On the design of grant assignment rules, by Francesca Modena, Santiago Pereda Fernandez and Giulia Martina Tanzi (December 2020).

N. 1308 - Monetary policy strategies in the New Normal: a model-based analysis for the euro area, by Fabio Busetti, Stefano Neri, Alessandro Notarpietro and Massimiliano Pisani (December 2020).

N.1309 - Rare disasters, the natural interest rate and monetary policy, by Alessandro Cantelmo (December 2020).

N.1310 - The market stabilization role of central bank asset purchases: high-frequency evidence from the COVID-19 crisis, by Marco Bernardini and Annalisa De Nicola (December 2020).

N. 1311 - Equity tail risk in the treasury bond market, by Dario Ruzzi and Mirco Rubin (December 2020).

N. 1312 - Scars of youth non-employment and labour market conditions, by Giulia Martina Tanzi (December 2020).

N. 1313 - The COVID-19 shock and a fiscal-monetary policy mix in a monetary union, by Anna Bartocci, Alessandro Notarpietro and Massimiliano Pisani (December 2020).

N.1314 - Working horizon and labour supply: the effect of raising the full retirement age on middle-aged individuals, by Francesca Carta and Marta De Philippis (February 2021).

N. 1315 - Bank credit and market-based finance for corporations: the effects of minibond issuances, by Steven Ongena, Sara Pinoli, Paola Rossi and Alessandro Scopelliti (February 2021).

N. 1316 - Is inflation targeting a strategy past its sell-by date?, by Alberto Locarno and Alessandra Locarno (February 2021).

N.1317 - Declining natural interest rate in the US: the pension system matters, by Jacopo Bonchi and Giacomo Caracciolo (February 2021).

N. 1318 - Can we measure inflation expectations using Twitter?, by Cristina Angelico, Juri Marcucci, Marcello Miccoli and Filippo Quarta (February 2021).

N. 1319 - Identifying deposits'outflows in real-time, by Edoardo Rainone (February 2021).

N.1320 - Whatever it takes to save the planet? Central banks and unconventional green policy, by Alessandro Ferrari and Valerio Nispi Landi (February 2021).

(*) Requests for copies should be sent to:

Banca d'Italia - Servizio Studi di struttura economica e finanziaria - Divisione Biblioteca e Archivio storico - Via Nazionale, 91 - 00184 Rome - (fax 003906 47922059). They are available on the Internet www.bancaditalia.it. 
ALBANESE G., M. CIOFFI and P. TOMMASINO, Legislators' behaviour and electoral rules: evidence from an Italian reform, European Journal of Political Economy, v. 59, pp. 423-444, WP 1135 (September 2017).

Aprigliano V., G. ARDizzI and L. MONTEFORTE, Using the payment system data to forecast the economic activity, International Journal of Central Banking, v. 15, 4, pp. 55-80, WP 1098 (February 2017).

ARnAudo D., G. MiCUCCI, M. RIGON and P. Rossi, Should I stay or should I go? Firms' mobility across banks in the aftermath of the financial crisis, Italian Economic Journal / Rivista italiana degli economisti, v. 5, 1, pp. 17-37, WP 1086 (October 2016).

BASSO G., F. D'AMURI and G. PERI, Immigrants, labor market dynamics and adjustment to shocks in the euro area, IMF Economic Review, v. 67, 3, pp. 528-572, WP 1195 (November 2018).

BAtini N., G. MELINA and S. VILla, Fiscal buffers, private debt, and recession: the good, the bad and the ugly, Journal of Macroeconomics, v. 62, WP 1186 (July 2018).

Burlon L., A. NotARPIETRO and M. PISANI, Macroeconomic effects of an open-ended asset purchase programme, Journal of Policy Modeling, v. 41, 6, pp. 1144-1159, WP 1185 (July 2018).

BUSETTI F. and M. CAIVANO, Low frequency drivers of the real interest rate: empirical evidence for advanced economies, International Finance, v. 22, 2, pp. 171-185, WP 1132 (September 2017).

CAPpelletti G., G. GuAZZAROtTI and P. TOMmasino, Tax deferral and mutual fund inflows: evidence from a quasi-natural experiment, Fiscal Studies, v. 40, 2, pp. 211-237, WP 938 (November 2013).

CARDANi R., A. PACCAGNINI and S. VILLA, Forecasting with instabilities: an application to DSGE models with financial frictions, Journal of Macroeconomics, v. 61, WP 1234 (September 2019).

Chiades P., L. Greco, V. Mengotto, L. Moretti and P. VAlbonesi, Fiscal consolidation by intergovernmental transfers cuts? The unpleasant effect on expenditure arrears, Economic Modelling, v. 77, pp. 266-275, WP 1076 (July 2016).

CIANI E., F. DAVID and G. DE BLASIO, Local responses to labor demand shocks: a re-assessment of the case of Italy, Regional Science and Urban Economics, v. 75, pp. 1-21, WP 1112 (April 2017).

CIANI E. and P. FISHER, Dif-in-dif estimators of multiplicative treatment effects, Journal of Econometric Methods, v. 8. 1, pp. 1-10, WP 985 (November 2014).

CIAPANNA E. and M. TABOGA, Bayesian analysis of coefficient instability in dynamic regressions, Econometrics, MDPI, Open Access Journal, v. 7, 3, pp.1-32, WP 836 (November 2011).

Coletta M., R. De Bonis and S. Piermattei, Household debt in OECD countries: the role of supply-side and demand-side factors, Social Indicators Research, v. 143, 3, pp. 1185-1217, WP 989 (November 2014).

Cova P., P. PAgAno and M. PISANI, Domestic and international effects of the Eurosystem Expanded Asset Purchase Programme, IMF Economic Review, v. 67, 2, pp. 315-348, WP 1036 (October 2015).

ERCOLANI V. and J. VALLE E AZEVEDO, How can the government spending multiplier be small at the zero lower bound?, Macroeconomic Dynamics, v. 23, 8. pp. 3457-2482, WP 1174 (April 2018).

FERrERo G., M. GROSS and S. NERI, On secular stagnation and low interest rates: demography matters, International Finance, v. 22, 3, pp. 262-278, WP 1137 (September 2017).

FoA G., L. GAmBACORTA, L. Guiso and P. E. Mistrulli, The supply side of household finance, Review of Financial Studies, v.32, 10, pp. 3762-3798, WP 1044 (November 2015).

GerAli A. and S. NERI, Natural rates across the Atlantic, Journal of Macroeconomics, v. 62, article 103019, WP 1140 (September 2017).

GIORDANO C., M. MARINUCCI and A. SILVESTRINI, The macro determinants of firms' and households' investment: evidence from Italy, Economic Modelling, v. 78, pp. 118-133, WP 1167 (March 2018).

GOMEllini M., D. PELlEGRINO and F. GIFFONI, Human capital and urban growth in Italy, 1981-2001, Review of Urban \& Regional Development Studies, v. 31, 2, pp. 77-101, WP 1127 (July 2017).

LiBERATI D. and M. LOBERTO, Taxation and housing markets with search frictions, Journal of Housing Economics, v. 46, article 101632, WP 1105 (March 2017).

MAGRI S., Are lenders using risk-based pricing in the Italian consumer loan market? The effect of the 2008 crisis, Journal of Credit Risk, v. 15, 1, pp. 27-65, WP 1164 (January 2018).

Mercatanti A., T. MAKINEN and A. SiLVESTRINI, The role of financial factors for european corporate investment, Journal of International Money and Finance, v. 96, pp. 246-258, WP 1148 (October 2017). 
Miglietta A., C. Picillo and M. PIETRUnTI, The impact of margin policies on the Italian repo market, The North American Journal of Economics and Finance, v. 50, WP 1028 (October 2015).

MONTEFORTE L. and V. RAPONI, Short-term forecasts of economic activity: are fortnightly factors useful?, Journal of Forecasting, v. 38, 3, pp. 207-221, WP 1177 (June 2018).

Neri S. and A. NotArpietro, Collateral constraints, the zero lower bound, and the debt-deflation mechanism, Economics Letters, v. 174, pp. 144-148, WP 1040 (November 2015).

PANCRAZI R. and M. PIETRUNTI, Natural expectations and home equity extraction, Journal of Housing Economics, v. 46, 4, WP 984 (November 2014).

Pereda FERnANDEZ S., Teachers and cheaters. Just an anagram?, Journal of Human Capital, v. 13, 4, pp. 635-669, WP 1047 (January 2016).

RigGi M., Capital destruction, jobless recoveries, and the discipline device role of unemployment, Macroeconomic Dynamics, v. 23, 2, pp. 590-624, WP 871 (July 2012).

AlessANDRi P. and M. BOTTERO, Bank lending in uncertain times, R European Economic Review, V. 128, WP 1109 (April 2017).

Antunes A. and V. ERCOlAnI, Public debt expansions and the dynamics of the household borrowing constraint, Review of Economic Dynamics, v. 37, pp. 1-32, WP 1268 (March 2020).

ARDUINI T., E. PATACCHINI and E. RAINONE, Treatment effects with heterogeneous externalities, Journal of Business \& Economic Statistics, , v. 38, 4, pp. 826-838, WP 974 (October 2014).

Bottero M., F. MeZZANOTTI and S. LENZU, Sovereign debt exposure and the Bank Lending Channel: impact on credit supply and the real economy, Journal of International Economics, v. 126, article 103328, WP 1032 (October 2015).

BRIPI F., D. LOSCHIAVO and D. REVELLI, Services trade and credit frictions: evidence with matched bankfirm data, The World Economy, v. 43, 5, pp. 1216-1252, WP 1110 (April 2017).

BRONZINI R., G. CARAMELLINO and S. MAGRI, Venture capitalists at work: a Diff-in-Diff approach at latestages of the screening process, Journal of Business Venturing, v. 35, 3, WP 1131 (September 2017).

BronzINI R., S. MocetTI and M. MONGARDINI, The economic effects of big events: evidence from the Great Jubilee 2000 in Rome, Journal of Regional Science, v. 60, 4, pp. 801-822, WP 1208 (February 2019).

COIBION O., Y. GORODNICHENKO and T. ROPELE, Inflation expectations and firms' decisions: new causal evidence, Quarterly Journal of Economics, v. 135, 1, pp. 165-219, WP 1219 (April 2019).

CORSELlO F. and V. NiSPI LANDI, Labor market and financial shocks: a time-varying analysis, Journal of Money, Credit and Banking, v. 52, 4, pp. 777-801, WP 1179 (June 2018).

COVA P. and F. NATOLI, The risk-taking channel of international financial flows, Journal of International Money and Finance, v. 102, WP 1152 (December 2017).

D'Alessio G., Measurement errors in survey data and the estimation of poverty and inequality indices, Statistica Applicata - Italian Journal of Applied Statistics, v. 32, 3, WP 1116 (June 2017).

Del Prete S. and S. FEDERICO, Do links between banks matter for bilateral trade? Evidence from financial crises, Review of World Economic, v. 156, 4, pp. 859 - 885, WP 1217 (April 2019).

D'IGNAZIO A. and C. MENON, The causal effect of credit Guarantees for SMEs: evidence from Italy, The Scandinavian Journal of Economics, v. 122, 1, pp. 191-218, WP 900 (February 2013).

ERCOLANI V. and F. NATOLI, Forecasting US recessions: the role of economic uncertainty, Economics Letters, v. 193, WP 1299 (October 2020).

MAKINEN T., L. SARNO and G. ZINNA, Risky bank guarantees, Journal of Financial Economics, v. 136, 2, pp. 490522, WP 1232 (July 2019).

MOdEnA F., E. RETTORE and G. M. TANZI, The effect of grants on university dropout rates: evidence from the Italian case, Journal of Human Capital, v. 14, 3, pp. 343-370, WP 1193 (September 2018).

NiSPI LANDI V., Capital controls spillovers, Journal of International Money and Finance, v. 109, WP 1184 (July 2018).

PERICOLI M., On risk factors of the stock-bond correlation, International Finance, v. 23, 3, pp. 392-416, WP 1198 (November 2018). 
RAINONE E., The network nature of OTC interest rates, Journal of Financial Markets, v.47, article 100525, WP 1022 (July 2015).

RAINONE E. and F. VACIRCA, Estimating the money market microstructure with negative and zero interest rates, Quantitative Finance, v. 20, 2, pp. 207-234, WP 1059 (March 2016).

RIZZICA L., Raising aspirations and higher education. Evidence from the UK's widening participation policy, Journal of Labor Economics, v. 38, 1, pp. 183-214, WP 1188 (September 2018).

SANTIONI, R., F. SCHIANTARELLI and P. STRAHAN, Internal capital markets in times of crisis: the benefit of group affiliation, Review of Finance, v. 24, 4, pp. 773-811, WP 1146 (October 2017).

SChiantarelli F., M. Stacchini and P. Strahan, Bank Quality, judicial efficiency and loan repayment delays in Italy, Journal of Finance, v. 75, 4, pp. 2139-2178, WP 1072 (July 2016).

\section{FORTHCOMING}

Accetturo A., A. LAmorgese, S. Mocetti and D. Pellegrino, Housing Price elasticity and growth: evidence from Italian cities, Journal of Economic Geography, WP 1267 (March 2020).

AlBAnese G., E. CIANI and G. DE BLASIO, Anything new in town? The local effects of urban regeneration policies in Italy, Regional Science and Urban Economics, WP 1214 (April 2019).

Albanese G., G. DE BlAsio and A. LOCATELLI, Does EU regional policy promote local TFP growth? Evidence from the Italian Mezzogiorno, Papers in Regional Science, WP 1253 (December 2019).

ANZUINI A. and L. Rossi, Fiscal policy in the US: a new measure of uncertainty and its effects on the American economy, Empirical Economics, WP 1197 (November 2018).

Bologna P., A. Miglietta and A. Segura, Contagion in the CoCos market? A case study of two stress events, International Journal of Central Banking, WP 1201 (November 2018).

Cova P., P. PAgAnO, A. NotARPIETRO and M. PisAni, Secular stagnation, R\&D, public investment and monetary policy: a global-model perspective, Macroeconomic Dynamics, WP 1156 (December 2017).

DE PHILIPPIS M., Multitask agents and incentives: the case of teaching and research for university professors, Economic Journal, WP 1156 (December 2015).

Del Prete S. and M. L. SteFAni, Women as "Gold Dust": gender diversity in top boards and the performance of Italian banks, Economic Notes, Monte dei Paschi di Siena, WP 1014 (June 2015).

Fidora M., C. GIORDANO and M. SchMitz, Real exchange rate misalignments in the Euro Area, Open Economies Review, WP 1042 (January 2018).

HERTWECK M., V. LEWIS and S. VILLA, Going the extra mile: effort by workers and job-seekers, Journal of Money, Credit and Banking, WP 1277 (June 2020).

Li F., A. MercatAnti, T. MAKINEN and A. SilveSTRINI, A regression discontinuity design for ordinal running variables: evaluating central bank purchases of corporate bonds, Annals of Applied Statistics, WP 1213 (March 2019).

LOSCHIAVO D., Household debt and income inequality: evidence from Italian survey data, Review of Income and Wealth, WP 1095 (January 2017).

METELli L. and F. NATOLI, The international transmission of US tax shocks: a proxy-SVAR approach, IMF Economic Review, WP 1223 (June 2019).

Mocetti S., G. RomA and E. RuBOLINO, Knocking on parents' doors: regulation and intergenerational mobility, Journal of Human Resources, WP 1182 (July 2018).

NisPi LANDI V. and A. SCHIAVONE, The effectiveness of capital controls, Open Economies Review, WP 1200 (November 2018).

PeReda Fernandez S., Copula-based random effects models for clustered data, Journal of Business \& Economic Statistics, WP 1092 (January 2017).

PERICOLI M. and M. TABOGA, Nearly exact Bayesian estimation of non-linear no-arbitrage term-structure models, Journal of Financial Econometrics, WP 1189 (September 2018). 